\title{
Bibliográfia
}

\section{A 2013-ban megjelent, jog- és államtudományi tárgyú könyvek annotált bibliográfiája}

\author{
2. rész
}

Folyóiratunkban rendszeresen jelenik meg az elmúlt időszak új, hazai szakkönyveiröl készült, annotált bibliográfia. Az annotáció a könyv felhasználhatóságáról írott, rövid, tényszerü leírás, amely a bibliográfiai adatok mellett meghatározza a müfajt, illetve röviden körvonalazza a feldolgozott témát és a bemutatott eredményeket is. A mostani számban a 2013-ban megjelent azon könyveket dolgozzuk fel, amelyekröl a 2015/1. számunkban nem közöltünk leírást. Annak megfelelöen, hogy a Magyar Tudományos Müvek Tára (MTMT) csak a 120 oldal terjedelmet elérő munkákat kezeli önálló kiadványként, az ettől jelentősen elmaradó kiadványokkal mi sem foglalkozunk. A bemutatás jogterületenként történik, a jogterületek elnevezésének, az egyes jogterületeken belül pedig a szerzők (szerkesztők) nevének ábécérendjében következik. Zárásként a vegyes tárgyú tanulmányköteteket ismertetjük.

Első lépésként ezúttal is egy listát állítottunk össze különböző intézményi könyvtári katalógusok, a Magyar Országos Közös Katalógus (MOKKA), illetve az Országos Széchényi Könyvtár interneten is közölt adatai alapján. Emellett kiadók honlapján, hírlevelekben, a szerzők publikációs listáiban és saját könyvespolcainkon is kutattunk. Gyüjtőmunkánkat jelentős mértékben segítette a Debreceni Egyetem Egyetemi és Nemzeti Könyvtára (DEENK), amely köteles könyvtárként a hazai kiadványok gyüjtését, feldolgozását, illetve részben - a mienkhez képest némileg eltérő szempontok szerint - annotálását is elvégzi. 2014-től kezdve a DEENK Társadalomtudományi Könyvtár munkatársai egyéb adatbázisokat is figyelembe véve egészítik ki a listánkat, így az még pontosabb és teljesebb a korábbiaknál. Külön köszönettel tartozunk nekik érte.

A leírások elkészítése során általában a szerzök, kiadók által készített fülszövegeket, ajánlásokat, illetve a kötetekröl készült recenziókat is igyekszünk fellelni és hasznosítani. Az annotációk azonban minden esetben úgy készültek, hogy magát az adott könyvet is a kezünkbe vettük, s ehhez, ha kellett, könyvtárközi kölcsönzéssel vagy más intézményekben dolgozó kollégáktól megkértük. Az annotációk tehát önálló feldolgozó munka eredményei.

Tisztában vagyunk azzal, hogy a feldolgozás szempontrendszere legjobb igyekezetünk ellenére is hiányos, illetve a sok szakterület és közremüködő okán egyenetlen. Örömmel veszünk és meg is szívlelünk ezért minden észrevételt, amely mun- 
kánkra vonatkozóan szerkesztöségünkhöz beérkezik. Szívesen fogadjuk azt is, ha a szerzők figyelmünkbe ajánlják saját könyvüket.

A leírások első, rövidebb része tartalmazza a könyvészeti adatokat (cím, szerző/szerkesztő, a kiadó neve, a kiadás helye és éve) az arra való utalással, hogy van-e a könyvben bibliográfia (irodalomjegyzék), illetve hogy a könyv milyen müfajba sorolható be. A terjedelmet oldalszámban adjuk meg, s közöljük a kötet azonosítására szolgáló ISBN-t, illetve sorozatok esetében az ISSN-t is. A második rész röviden leírja az alkotót, illetve alkotókat. Ezt követően (a változatlan utánnyomások kivételével) általában 6-12 sor terjedelemben számba vesszük a mü tárgyköreit, föbb eredményeit. Az eredmények részletes értékelését azonban nem végezzük el. A sokszerzős, illetve a gyüjteményes munkák esetében nem kerül sor valamennyi szerző név szerinti megemlítésére, s a tanulmányok számától, tematikai egymáshoz kapcsolódásától függ, hogy minden témát megnevezünk-e. A felsőoktatási tananyagok, jogszabályközlések bemutatását a lehetö legtömörebben végezzük el.

Az annotációk szerzői valamilyen formában kivétel nélkül kapcsolódnak a Debreceni Egyetem Állam- és Jogtudományi Karához, legyen szó munkatársainkról, óraadóinkról vagy jelenlegi és volt hallgatóinkról. Az annotációk végén szereplő monogramok feloldása a következő: Balogh Éva (B. É.) PhD-hallgató, Bagdi Katalin (B. K.) PhD-hallgató, Bagossy Mária (B. M.) joghallgató, Balogh Judit (B. J.) habilitált egyetemi docens, Barta Attila (Ba. A.) egyetemi adjunktus, Becánics Adrienn (B. A.) egyetemi tanársegéd, Belinszky Adrienn (Be. A.) PhD-hallgató, Besenyei Fruzsina (B. F.) joghallgató, Bodó László (B. L.) abszolvált PhD-hallgató, Bordás Péter (B. P.) PhD-hallgató, Bujdos Ágnes (B. Á.) PhD-hallgató, Deák Viktória (D. V.) PhDhallgató, Fazekas Flóra (F. F.) egyetemi adjunktus, Fodor László (F. L.) egyetemi tanár, Gócza Ágnes (G. Á.) PhD-hallgató, Kanyuk Petra Ágnes (K. P. Á.) joghallgató, Kémeri Zsófia (K. Zs.) PhD-hallgató, Kiss János Márk (K. J. M.) PhD-hallgató, Nyilas Anna (Ny. A.) egyetemi adjunktus, Pádár Henrietta (P. H.) joghallgató, Pápai-Tarr Ágnes (P. T. Á.) egyetemi adjunktus, Papp László (P. L.) egyetemi adjunktus, Papp Nikolett (P. N.) egyetemi tanársegéd, Papp Olga (P. O.) PhD-hallgató, Pető Alexandra (P. A.) abszolvált PhD-hallgató, Szabó Zsanett (Sza. Zs.) PhD-hallgató, Szabó Zsuzsanna (Sz. Zs.) egyetemi tanársegéd, Szemesi Sándor (Sz. S.) habilitált egyetemi docens, Tomasovszky Edit (T. E.) PhD-hallgató, Varga Judit (V. J.) egyetemi tanársegéd, Veszprémi Bernadett (V. B.) egyetemi adjunktus, Zsugyó Virág (Zs. V.) PhD-hallgató.

\section{ALKOTMÁNYJOG}

- Az alapjogvédelem nemzeti, nemzetközi és jogösszehasonlító aspektusai

Antal Tamás-Papp Tekla (szerk.)

(Sorozat: Lectiones luridicae, ISSN 2062-5588; 8.)

Pólay Elemér Alapítvány, Szeged, 2013

Tanulmánykötet. Terjedelem: 132. Bibliográfia a lábjegyzetekben. ISBN 9786155300158 
- A kötet az MTA Szegedi Akadémiai Bizottsága Jogi Szakbizottságának Gazdasági Jogi Munkacsoportja és a Europe Direct Szeged tudományos ülésén elhangzott előadások tanulmányokká átdolgozott változatait tartalmazza. A tanulmányok egy része valamilyen módon az alapjogokhoz kapcsolódik, rendkívül változatos területeken. Megjelenik az alapjogok történeti és jogelméleti háttere, az Európai Unió alapjogvédelmi rendszere, a tulajdonhoz való jog különböző vonatkozásokban, az alapjogok érvényesülése a munkajogban. Emellett az önkormányzati rendszert, a tisztességes gazdasági verseny közbeszerzési eljárás során való érvényesülését vagy a fogyasztó fogalmának anomáliáit érintő tanulmányokat is tartalmaz a kötet. (B. É.)

- Alkotmányjog: emberi jogok, státusjogok, jogforrási rendszer. C/2. Témakör: Alkotmányjog és közigazgatási jog

CHRONOWSKI Nóra

(Sorozat: Dialóg Campus Szakkönyvek, ISSN 1417-7986; Jogi Szakvizsga Segédkönyvek, ISSN 1587-6659)

Negyedik, jelentősen átdolgozott kiadás. Dialóg Campus, Budapest-Pécs, 2013 Tankönyv. Terjedelem: 295. Bibliográfia a lábjegyzetekben. ISBN 9786155376078

- A szerző egyetemi oktató. A könyv elsősorban a szakvizsgára készülők számára nyújt segítséget alkotmányjogból, immár az Alaptörvényre, annak módosításaira és az erre épülő másodlagos joganyagra tekintettel. Az egyes fejezetek a szakvizsga-követelmények alapján dolgozzák fel a címben megjelölt témakörökhöz tartozó tételek anyagát, így az alapjogok feldolgozását az állampolgársági jog és a nemzetiségekre vonatkozó szabályozás áttekintése követik, majd a népszavazásra és a népi kezdeményezésre, illetve az egyes választási eljárásokra vonatkozó hatályos szabályozás, végül pedig a jogforrási rendszer kerül bemutatásra. A kötet feldolgozza a vonatkozó alkotmánybírósági határozatokat is. (B. É.)

\section{- Tanulmányok a választási eljárás aktuális kérdéseiről}

Cserny Ákos-Téglási András (szerk.)

NKE-Nemzeti Közszolgálati és Tankönyv Kiadó, Budapest, 2013

Konferenciakötet. Terjedelem: 127. Bibliográfia a lábjegyzetekben. ISBN 9786155305030

- A kötet a Nemzeti Közszolgálati Egyetem Közigazgatás-tudományi Karának Közjogi Intézete által 2012. november 29-én megrendezett konferencián elhangzott tudományos elöadások anyagát adja közre. Az új választási törvény elfogadásának apropóján a választási eljárás számos aspektusát tárgyaló konferencián egyetemi oktatók, az ombudsmani hivatal, az adatvédelmi hatóság és az Országos Választási Bizottság munkatársai, illetve politikai elemzőintézetek választási szakértői vettek részt. A tanulmányok vizsgálják többek között a választási intézményeket (például a választási regisztráció intézményét), adatvédelmi kérdéseket, a választási csalások megelőzhetőségét és a választásokon való részvétel feltételeit. (B. É.) 
- Az olasz alkotmány: alkotmánytörténet, alkotmányelmélet, alkotmányos rendelkezések

EGRESI Katalin

Gondolat, Budapest, 2013

Monográfia. Terjedelem: 306. Bibliográfia: 265-268. ISBN 9789636935085

- A szerző a Széchenyi István Egyetem docense. Kötete Olaszország 1948-ban hatályba lépett köztársasági alkotmányát tárgyalja tág perspektívából, hiszen nemcsak az alkotmány egyes rendelkezéseit elemzi, hanem az annak elfogadását megelőző jogi, politikai és filozófiai megfontolásokat is. A könyv első része alkotmánytörténeti témájú, amiből megismerhetjük az alkotmány elfogadásához vezetö történelmi folyamatokat és az olasz közjogtudományi gondolkodás föbb vonalait. Ezt követően a kötet az olasz alkotmány egyes rendelkezéseit vizsgálja: elsőként az alapelveket, majd az alapjogokat, végül az államszervezetet. (Zs. V.)

- Megosztott liberalizmus - A szólásszabadság és az államhatalom sokféle arca Fiss, Owen M.

Hammer Ferenc ford.

CompLex, Budapest, 2013

Monográfia. Terjedelem: 246. Bibliográfia: 236. és a lábjegyzetekben. ISBN 9789632953311

- A szerző egyetemi oktató az USA-ban, e monográfiája hazájában 1966-ban jelent meg, a magyar fordítás 2013-ban készült el. Kötetében a szólásszabadság liberálisnak nevezett támogatóival szemben fogalmazza meg a szólásszabadság állam általi korlátozása melletti érveit és a liberális szólásszabadságra vonatkozó kritikáit. Állítása szerint a liberálisok felfogása nem egységes, önmagukkal is harcban állnak, a szólásszabadság-vita egyes érzékeny kérdéseiben olykor önmaguknak is ellentmondó áláspontokat képviselnek. A szerző e gondolatmenet mentén teszi vizsgálat tárgyává a szólásszabadság különböző területeivel, korlátaival (gazdasági és politikai hatalom összefüggései, tartalmon alapuló szabályozások, állami beavatkozás a médiába) kapcsolatos álláspontokat és az amerikai esetjogot. A kötethez Koltay András, a Médiatanács tagja írt utószót. (B. É.)

- Kommentár az egészségügyi adatvédelmi törvényhez: Kommentár az egészségügyi és a hozzájuk kapcsolódó személyes adatok kezeléséröl és védelméről szóló 1997. évi XLVII. törvényhez

HANTI Péter

Wolters Kluwer, Budapest, 2013

Kommentár. Terjedelem: 248. Bibliográfia nincs. ISBN 9789632952352

- A szerző orvos-jogász, igazságügyi szakértő. A kötet a címben szereplö, az információs önrendelkezési jog szempontjából kiemelt jelentőségü törvény hatályos, az információs jogokról szóló új, 2011. évi CXII. törvénnyel összhangba hozott rendelkezéseit magyarázza, és ismerteti a kapcsolódó joggyakorlatot is. (B. É.) 
- A jogalkotásban való társadalmi részvételröl: tanulmány- és konferenciakötet Közigazgatási és Igazságügyi Minisztérium (szerk.)

Közigazgatási és Igazságügyi Minisztérium, Budapest, 2013

Tanulmány/konferenciakötet. Terjedelem: 129. Bibliográfia a lábjegyzetekben. ISBN nincs

- A kötet, melynek szerzői egyfelöl a jogtudomány képviselői, másfelöl a jogalkotás előkészítésében közremüködő gyakorlati szakemberek, a jogalkotásban való társadalmi részvétel újabb, a technikai fejlődés (elsősorban az internet) nyomán megjelenő aspektusaival és jelenségeivel foglalkozik. A kötet első része önálló tanulmányokat közöl ebben a témakörben, például a helyi szintű jogalkotással vagy a civilszervezetek tapasztalataival kapcsolatban. A második rész a 2013. június 27-én Budapesten a jogalkotásban való társadalmi részvételröl szóló törvény utólagos hatásvizsgálatával foglalkozó konferencián elhangzott előadások vázlatait (posztereit) tartalmazza. A kötet a részvételi törvény utólagos hatásvizsgálata során beérkezett civil észrevételek összegzésével zárul. (B. É.)

- A nemzetiségi önkormányzatok kézikönyve: a nemzetiségek jogairól szóló törvények magyarázata nem csak nemzetiségi önkormányzatoknak

LATORCAI Csaba-Molnárné Asbóth Erika-Paulik Antal

Emberi Erőforrások Minisztériuma Egyházi, Nemzetiségi és Civil Társadalmi Kapcsolatokért Felelős Államtitkársága, Budapest, 2013

Kézikönyv/kommentár. Terjedelem: 182. Bibliográfia a lábjegyzetekben. ISBN 9786155239175

- A szerzők a nemzetiségi politika területén dolgozó kormányzati szakemberek. Kiadványuk célja, hogy - elsősorban, de nem kizárólag a nemzetiségi önkormányzatok számára - segítséget nyújtson az új nemzetiségi törvény (a nemzetiségek jogairól szóló 2011. évi CLXXIX. törvény, Njtv.) áttekintéséhez, értelmezéséhez és alkalmazásához. Ennek érdekében a kötet a törvény egyes fejezeteinek áttekintésével, a jogszabály egyes szakaszainak magyarázatával és esetenként példák bemutatásával segíti az igen terjedelmes, nehezen áttekinthető és lépcsőzetesen hatályba lépő új szabályozás megismerését. (F. F.)

\section{- Migrációs antológia}

Ördög István (szerk.)

Bevándorlási és Állampolgársági Hivatal Tudományos Tanácsa, Budapest, 2013 Tanulmánykötet. Terjedelem: 205. Bibliográfia az egyes tanulmányok végén és a lábjegyzetekben. ISBN 9789630882828

- A kötet szerzői menekültügyi, idegenrendészeti szakemberek, kormánytisztviselök. A kötet célja a migrációhoz kapcsolódó egyes jelenségek, így a menekültügy, az idegenrendészet és az állampolgársági jog különböző aspektusainak tudományos igényű bemutatása európai és nemzetközi tapasztalatok alapján. A közreadott tanulmányok, amelyek 2009-2010-es lezárásúak, érintik egyebek mellett a többes állampolgárság kérdését, a menekültügyi őrizet intézményét, a családi élet védelmét mint a kiutasítás akadályát, és a menekültkénti elismerést kizáró okokat. (F. F.) 
- Migration Anthology

Ördög, István (szerk.)

Scientific Council of Office of Immigration and Nationality, Budapest, 2013

Tanulmánykötet. Terjedelem: 209. Bibliográfia az egyes tanulmányok végén és a lábjegyzetekben. ISBN 9789630882835

- A fent ismertetett „Migrációs antológia” címü kötet angol nyelvü kiadása. (F. F.)

- Magyar sajtószabadság és -szabályozás 1914-1989: Előadások a magyar sajtószabadság történetéhez (Budapest, 2012. november 15.)

Paál Vince (szerk.)

(Sorozat: Médiatudományi Könyvtár; 6.)

Médiatudományi Intézet, Budapest, 2013

Konferenciakötet. Terjedelem: 98. Bibliográfia a lábjegyzetekben.

ISBN 9786155302022

- A kötet a Magyar Tudományos Akadémia Bölcsészettudományi Kutatóközpontjának Médiatudományi Kutatócsoportja és a Médiatanács Médiatudományi Intézete által 2012 novemberében rendezett azonos című konferencia előadásainak szerkesztett változatait tartalmazza. Az előadók a sajtószabadság tartalmát és érvényesülését vizsgálták a címben megjelölt korszak különböző időszakaiban. Bemutatják a Horthy-korszak, az 1914-1944 közötti Magyarország és a Délvidék, illetve a Sztálin halálától a Helsinki Záróokmányig tartó időszak magyarországi sajtószabályozását és a sajtószabadság érvényre jutását. Egy további tanulmány az elektronikus sajtó szabályozásának magyarországi kezdő lépéseit tárgyalja a rádió szabályozásán keresztül, az utolsó írás pedig a szovjet típusú diktatúra cenzúramechanizmusait tekinti át. (B. É.)

- Magyarország alkotmányjoga I.: Alapvetés, alkotmányos intézmények

PETRÉTEl József

Kodifikátor Alapítvány, Pécs, 2013

Tankönyv. Terjedelem: 343. Bibliográfia az egyes fejezetek végén.

ISBN 9789638991201

- A szerző egyetemi tanár. A kétkötetes munkával az Alaptörvényhez és a kapcsolódó sarkalatos törvényekhez igazított, az egyetemi oktatásban sikerrel hasznosítható, időszerű tankönyv elkészítése volt a célja. Az első kötet az alkotmányjog alapjait tárgyalja, így az alkotmányjog jellemzőivel, az Alaptörvény jellegével, az alapelvekkel, a jogforrásokkal, az állampolgársággal, az országgyülési képviselők választásával, a helyi önkormányzati választásokkal, az országos népszavazással és a népi kezdeményezéssel, illetve a politikai pártokkal kapcsolatos alkotmányjogi ismereteket tartalmazza. (B. É.)

\section{- Magyarország alkotmányjoga II.: Államszervezet}

Petrétel József

Kodifikátor Alapítvány, Pécs, 2013

Tankönyv. Terjedelem: 394. Bibliográfia az egyes fejezetek végén.

ISBN 9789630863599 
- A szerző egyetemi tanár. A kétkötetes munkával az Alaptörvényhez és a kapcsolódó sarkalatos törvényekhez igazított, az egyetemi oktatásban sikerrel hasznosítható, időszerü tankönyv elkészítése volt a célja. A második kötet az Alaptörvény államszervezeti struktúráját mutatja be. Az átfogó, az államszervezetet általánosságban jellemző bevezető fejezetet követően a föbb alkotmányos intézmények (Országgyülés, köztársasági elnök, Kormány, Alkotmánybíróság stb.) ismertetése következik, majd önálló fejezet tárgyalja a közpénzekre, a honvédségre és a rendőrségre vonatkozó szabályozást. (B. É.)

- A válság vesztesei - a paragrafusok fogságában projekt

Szajbély Katalin (szerk.)

(Sorozat: AJB Projektfüzetek, ISSN 2063-3645; 2013/3.)

Alapvető Jogok Biztosának Hivatala, Budapest, 2013

Projektfüzet. Terjedelem: 186. Bibliográfia: 186. és a lábjegyzetekben.

ISBN 9789638968234

- A kötet az alapvető jogok biztosa és munkatársai által 2012-ben megvalósított projekt eredményeit foglalja össze. A projekt célja az volt, hogy megvilágítsa: milyen módon hat ki a gazdasági és pénzügyi válság, illetve az azzal párhuzamosan megjelenő morális, társadalmi, jogalkotási/jogalkalmazási válság az alapvető jogok, különösen a nemzetiségi és környezeti jogok érvényesülésére. A vizsgálat elsősorban a társadalom egyébként is sérülékeny csoportjaira (pl. nemzetiségek, idősek, betegek, hajléktalanok), illetve a jelentős állami forrást igénylő ellátási területekre (pl. egészségügy, környezetvédelem) fókuszált, és az említett szempontokat egy meghatározott szükebb térségben (Szentgotthárd és környéke) átfogóan is vizsgálta. A projekt eredményeként számos jelentés, javaslat, alkotmánybírósági indítvány és publikáció született, melyek lényegét e kötet ismerteti. (F. F.)

- Applicatio est vita regulae - nemzetközi jogesetek a parlamenti jog köréböl Szente Zoltán (szerk.) Universitas-Györ Kft., Győr, 2013 Jogesettár. Terjedelem: 148. Bibliográfia a lábjegyzetekben. ISBN 9786155298110

- A kötet szerzői a Parlamenti Kutatások Központjának tagjai, akik egyben a Széchenyi István Egyetem Alkotmányjogi Tanszékének munkatársai. A kötet célja, hogy bemutassa a legjelentősebb, leghíresebb parlamenti tárgyú külföldi jogesetek egy részét. A szerzők négy fejezetben 24 jogesetet ismertetnek a törvényhozó hatalom alkotmányos korlátairól, a törvényhozás hatásköreiröl, a parlamentek müködéséröl és a parlamenti képviselök jogállásáról. Ennek keretében olyan elhíresült esetek kerülnek bemutatásra, mint például a Bonham-ügy, a Marbury versus Madison ítélet vagy a spanyol alkotmánybíróság döntése a katalán autonómiastatútumról. (Zs. V.) 
- Egy müködő szakrális jogrend: a katolikus egyház jogának néhány sajátos fogalma és intézménye

SzURomı Szabolcs Anzelm

(Sorozat: Bibliotheca Instituti Postgradualis luris Canonici Universitatis Catholicae de Petro Pázmány Nominatae. III. Studia, 1585-857X; 16.)

Szent István Társulat, Budapest, 2013

Monográfia. Terjedelem: 177. Bibliográfia: 160-177. és a lábjegyzetekben. ISBN 9789632774190

- A szerző a Pázmány Péter Katolikus Egyetem egyetemi tanára, teológus, kánonjogász. A kötet az egyes kánonjogi intézmények komplex vizsgálatát tüzi célul, így nemcsak a hatályos szabályokra tér ki, hanem jogtörténeti elemzéseket is tartalmaz. A kötet tíz fejezetböl áll, melyek tárgyalják például az egyedi közigazgatási intézkedések kánoni forrásait, a káptalani hivatalok betöltésének szabályait, az egyházi anyakönyvekre, a keresztség kiszolgáltatására, a temetőkre, az egyházi tizedre vonatkozó szabályokat, illetve a kánonjog szerinti legsúlyosabb bűncselekményeket is. (Zs. V.)

- Legistica: a jogalkotástan vázlata

TAMÁs András

Hetedik, átdolgozott kiadás. Nemzeti Közszolgálati és Tankönyv Kiadó, Budapest, 2013

Tankönyv. Terjedelem: 312. Bibliográfia: 309-312. ISBN 9786155344145

- A szerző egyetemi tanár. Az átdolgozott, hatályosított kiadásban megjelent munka az alkotmányjogi stúdium egyik legalapvetőbb jelentőségü területét, a jogszabályok megalkotására vonatkozó szerteágazó ismeretanyagot tekinti át. A témát két nagy egységben dolgozza fel: a jogszabálytan a jogszabály fogalmával, normatív tartalmával és szerkezetével foglalkozik, a második egység pedig a jogalkotásra mint folyamatra fókuszál, így kitér többek között a technológiai sajátosságokra, a jogalkotásformákra és a jogszabályrendezés módozataira. A függelék a jogalkotással kapcsolatos hatályos (2009-2010-ben elfogadott) törvényeket és rendeleteket tartalmazza. (F. F.)

- Az új Alaptörvény és a jogélet reformja = The New Hungarian Constitution and Reforms in Legal Life = Das neue Ungarische Grundgesetz und Reformen im Rechtsleben

Varga Norbert (szerk.)

(Sorozat: Szegedi Jogász Doktorandusz Konferenciák, ISSN 2063-3807; 2.)

SZTE Állam- és Jogtudományi Doktori Iskola, Szeged, 2013

Konferenciakötet. Terjedelem: 362. Bibliográfia a lábjegyzetekben.

ISBN 9789633061428

- A szerkesztő egyetemi oktató. A Szegedi Tudományegyetem Állam- és Jogtudományi Doktori Iskolájában hagyománnyá vált a doktoranduszkonferenciák rendszeres megrendezése. A kötet a 2011. november 30-án tartott doktoranduszkonferencián elhangzott előadások bővített, tanulmányokká átdolgozott előadásait tartalmazza. A konferencia központi témája Magyarország új Alaptörvénye volt, 
így az elöadók különböző megközelítésekkel, interdiszciplináris jelleggel vizsgálták az Alaptörvény tartalmát, és fogalmaztak meg kritikát annak rendelkezéseivel kapcsolatban. A kötetben található harminc, magyar és angol nyelvű tanulmány különböző jogterületeken (pl. alapjogok, pénzügyi jog, büntetőjog, civilisztika) elemzi az Alaptörvény által hozott változásokat. (B. É.)

\section{BÜNTETŐJOG, BÜNTETŐ ELJÁRÁSI JOG}

- Tanulmányok a bünügyi tudományok köréböl

Bragyova András (szerk.)

(Sorozat: Doktori Tankönyvek, ISSN 1787-2197)

Gazdász-Elasztik Kft., Miskolc, 2013

Tanulmánykötet. Terjedelem: 197. Bibliográfia a lábjegyzetekben. ISBN 9789638773876

- A szerzők a Miskolci Egyetem Állam- és Jogtudományi Karának oktatói. A kötet elsősorban a büntetőjog területén kellő alapismeretekkel bíró doktoranduszhallgatók számára készült. A tanulmányok többsége a büntető anyagi jogot érintő nagyobb témák köréböl nyújt áttekintést (például a nemzetközi büncselekmények, a resztoratív büntetőjog vagy a csődbüncselekmények tárgykörében), két írás büntetőeljárás-jogi kérdésekkel foglalkozik, a gyermek- és fiatalkori bünözés alapkérdéseiről pedig kriminológiai megközelítésben olvashatunk. (K. P. Á.)

- Büntetö anyagi jog I. és III. az új Btk. alapján

Deres Petronella-Domokos Andrea

(Sorozat: Wesselényi-sorozat)

Patrocinium, Budapest, 2013

Egyetemi jegyzet. Terjedelem: 112. (I. kötet), 142. (III. kötet). Bibliográfia nincs. ISBN 9786155337345 (I. kötet), 9786155337406 (III. kötet)

- A szerzők egyetemi oktatók. A négykötetes jegyzet, melynek II. és IV. kötete 2014ben jelent meg, a büntetőjog tantárgy előadásainak vázlatait tartalmazza. Az első kötet a büntetőjogi alapismereteket vázolja (alapelvek, büncselekmény fogalma, büncselekmény tárgyi oldalának elemei, büntetőjogi felelősségre vonás akadályai, büntethetőséget megszüntető okok), a harmadik kötet pedig az új Btk. XV. és XVII-XXII. fejezeteiben található bűncselekmények törvényi tényállásait mutatja be. (Be. A.)

- Bejelentés vagy feljelentés? A pénzmosás és a terrorizmus finanszírozása elleni küzdelemmel kapcsolatos feladatok és kötelezettségek az Új Büntető Törvénykönyv alapján

GÁL István László

Második kiadás. Penta Unió, Pécs, 2013

Monográfia. Terjedelem: 206. Bibliográfia a lábjegyzetekben.

ISBN 9786155249068 
- A szerző egyetemi oktató, könyvének első kiadása 2009-ben jelent meg. A pénzmosással kapcsolatos joganyag azóta számottevően megváltozott, ez indokolta a kötet átdolgozását. A 2012. évi C. törvény, az új Btk. pénzmosással kapcsolatos szabályainak egyik legfontosabb változása, hogy önáló büncselekményként került szabályozásra a terrorizmus finanszírozása, és ugyancsak büncselekményt valósít meg a pénzmosás bejelentésének elmulasztása, illetve a terrorizmus finanszírozásának megelőzésével és megakadályozásával kapcsolatos bejelentési kötelezettség elmulasztása. Mivel ez utóbbi bűncselekmény tettesei csak azok lehetnek, akiket a törvény bejelentési kötelezettséggel terhel, a pénzmosás szabályainak alapos ismerete a pénzügyi szolgáltató szférában dolgozó valamennyi szakember elemi érdeke. A könyv elsősorban számukra, könyvelök és könyvvizsgálók számára készült, azonban a gyakorlatias megközelítés mellett a téma megfelelö elméleti megalapozását is adja. (P. T. Á.)

\section{- Kriminológia-Szakkriminológia}

Gönczöl Katalin-Kerezsi Klára-Korinek László-Lévay Miklós (szerk.) CompLex, Budapest, 2013

Tankönyv. Terjedelem: 708. Bibliográfia a fejezetek végén. ISBN 9789632248929

- A könyv alapvető célja a felsőoktatásban részt vevők számára a kriminológia egészének, illetve egyes szakkriminológiai területek ismeretanyagának tudományos igényű, ugyanakkor közérthető és az olvasó számára is élvezetes bemutatása. Azoknak a szakoknak a hallgatói számára készült, amelyeken kriminológiát, illetve a bünözés kérdéskörével kapcsolatos ismereteket oktatnak. A szerzők a kötetet szakkönyvnek is szánják. A 25 fejezetet tartalmazó tankönyv 18 szerző munkájával készült. A mủ három szerkezeti egységböl áll. Az első rész tudományelméleti, tudománytörténeti és a bünözés megismerésével, értelmezésével kapcsolatos fejezeteket tartalmaz. A második rész a kriminológiai szempontból leglényegesebb bűncselekmény- és bünelkövetői csoportokra vonatkozó ismereteket mutatja be. Az utolsó rész a bünözésre való reagálás kriminológiailag releváns kérdéseit bemutató fejezeteket tartalmazza. (G. Á.)

\section{- Válogatás a 2012-ben tartott tudományos ülések előadásaiból} Kiss Valéria (szerk.)

(Sorozat: Kriminológiai Közlemények, ISSN 0236-9893; 72.)

Magyar Kriminológiai Társaság, Budapest, 2013

Tanulmánykötet. Terjedelem: 183. Bibliográfia a lábjegyzetekben. ISBN 9789638016249

- A Magyar Kriminológiai Társaság folyamatos működésének bizonyítékát jelentik az évente több alkalommal szervezett tudományos ülések és kerekasztal-beszélgetések, s az ezeken elhangzott előadások anyaga rendszeresen megjelenik a Kriminológiai Közlemények sorozatban. Jelen kötet a társaság 2012-es rendezvényeinek elöadásaiból válogat, képet adva ezzel az aktuális kriminálpolitikai változásokról. Az évet a fedett nyomozás kérdéseivel foglalkozó tudományos ülés nyitotta, amelyet a „Csapda” címü film bemutatása alkalmával rendezett kerek- 
asztal-beszélgetés követett. Majd a pénzmosásról, az átalakulóban lévő gyermekvédelemröl szóló ülések anyagai, a szakértői bizonyítás kérdésköre, végül a viktimológiai szekció előadásai következnek. (K. P. Á.)

- A korrupció okai, terjedése és kezelése

MAJstorović Nebojša

Pásztor Kicsi Mária (ford.)

Gondolat, Budapest, 2013

Monográfia. Terjedelem: 127. Bibliográfia: 117-125. ISBN 9789636934897

- A szerző az Újvidéki Egyetem oktatója. A mü helyi közösségeket alapul véve tárja fel a korrupció kiterjedésének és intézményesülésének metódusát. Büntetőjogi szemlélet mellett pszichológiai megoldásokat is kínál a korrupció felszámolására, az adott szervezetek rehabilitációjára és eme jelenség megelőzésére. A monográfia célja áttekinteni a korruptív viselkedés megjelenési formáit, azoknak személyes és társadalmi következményeit, továbbá a korrupciónak egyes közösségekben való meglétének mérési lehetőségeit. (G. Á.)

- Régi és új tendenciák a büntetőjogban és a büntetőjog-tudományban NAGY Ferenc

(Sorozat: Értekezések a jogtudomány köréböl, ISSN 2062-9222)

Akadémiai, Budapest, 2013

Monográfia. Terjedelem: 193. Bibliográfia: 175-193. ISBN 9789630594202

- A szerző egyetemi tanár, a Szegedi Tudományegyetem oktatója. A kötet tizenegy fejezetben tárgyalja a büntetőjog és a büntetőjog-tudomány régi és legújabb fejlődési tendenciáit. Olyan állandóan aktuális kérdéseket jár körül, mint például a büntetőjognak az erkölccsel való kapcsolata, a büntetőjog közös európai gyökerei, a büntetőjog feladata, a dogmatika és kriminálpolitika viszonya, a hazai büntetőjog-tudomány előzményei és fejlődéstörténete. A büntetőjog újabb tendenciái közül a büntetendőség határainak kiterjesztésével, a szimbolikus büntetőjoggal, a jóvátétel büntetőjogban való megjelenésével és a jogállami büntetőjog eróziójával foglalkozik. A függelékben a magyar büntetőjog tudományának kiemelkedő képviselöiről készített összeállítást ad közre. (P. T. Á.)

- Új Btk. kommentár

Polt Péter (főszerk.)

Nemzeti Közszolgálati és Tankönyv Kiadó, Budapest, 2013

Kommentár. Bibliográfia a fejezetek végén.

1. kötet - Általános rész - Terjedelem: 215 - ISBN 9786155344152

2. kötet - Általános rész - Terjedelem: 231 - ISBN 9786155344169

3. kötet - Különös rész - Terjedelem: 294 - ISBN 9786155344176

4. kötet - Különös rész - Terjedelem: 216 - ISBN 9786155344183

5. kötet - Különös rész - Terjedelem: 256 - ISBN 9786155344190

6. kötet - Különös rész - Terjedelem: 208 - ISBN 9786155344206

7. kötet - Különös rész - Terjedelem: 224 - ISBN 9786155344213

8. kötet - Különös rész - Terjedelem: 327 - ISBN 9786155344220 
- A Kommentár szerzői neves elméleti és gyakorlati szakemberek. A Kommentár szerkesztése során arra törekedtek, hogy világos, egyértelmű, irányadó bírósági döntésekkel alátámasztott magyarázatokkal szolgáljanak az egyes törvényi szabályokhoz. Átlátható szerkesztési elv szerint, minden szakaszt szövegmagyarázat követ, amelyben egyaránt helyet kap a jogintézmények történeti bemutatása, a szakaszok tudományos, részletes elemzése és a bírói gyakorlat is. Állásfoglalásaikat úgy alakították ki, hogy az a legnagyobb mértékben megfeleljen a jogalkotói szándékot alakító jogpolitikának és annak a dogmatikai rendszernek, amely a 2012. évi C. törvényben megvalósul. Elsősorban a jogalkalmazóknak szól a Kommentár, de széles értelemben a jogkereső nagyközönség számára és a jogi oktatás számára is használható. (Be. A.)

\section{EURÓPA-JOG ÉS NEMZETKÖZI JOG}

- Erősödő Európa

ANDOR László

Kossuth, Budapest, 2013

Monográfia. Terjedelem: 173. Bibliográfia: 163-173. ISBN 9789630977074

- A szerző közgazdász, 2009-2014 között az Európai Bizottság foglalkoztatásért, szociális ügyekért és társadalmi összetartozásért felelös biztosa. A kötet célja az Unió szociális helyzetének szemléltetése, főként a munkanélküliség és szegénység szociálpolitikáján keresztül. 11 fejezetben kerül ismertetésre többek között a versenyképes és szociális piacgazdaság jelene és jövője, a válságkezelés és az ehhez kapcsolódó fellendülési stratégia, valamint az ifjúsági munkanélküliség mint speciális probléma az Európai Unió rendszerében. (B. F.)

- Emlékkötet Herczegh Géza születésének 85. évfordulójára: a ius in bello fejlödése és mai problémái

Csapó Zsuzsanna (szerk.)

Pécsi Tudományegyetem Állam- és Jogtudományi Kara, Pécs, 2013

Tanulmánykötet. Terjedelem: 307. Bibliográfia a jegyzetekben.

ISBN 9789636425746

- Herczegh Géza több mint két évtizeden át állt a pécsi Nemzetközi Jogi Tanszék élén. 1990-ben az Alkotmánybíróság tagjává, majd 1993-ban a hágai Nemzetközi Bíróság tagjává választották. Az emlékkötet alcíme és egyben a tanulmányok tárgya tisztelgés Herczegh Géza 1981-ben megjelent monográfiája („A humanitárius nemzetközi jog fejlödése és mai problémái”) elött. A tanulmánykötet szerzői között a pécsi nemzetközi jogász kollégákon kívül valamennyi jogi kar humanitárius nemzetközi joggal foglalkozó oktatói egyaránt megtalálhatóak. (Sz. S.)

- Alapvető tények az ENSZ-röl Liwa-Horváth Krisztina (ford.) Magyar ENSZ Társaság, Budapest, 2013 Kézikönyv. Terjedelem: 327. Bibliográfia nincs. ISBN 9789638972804 
- A kézikönyv átfogó ismeretet nyújt a nemzetközi szervezetek létrejöttéröl, felépítéséröl, valamint struktúrájáról. Nem csupán a föbb szerveit mutatja be, hanem az egyes programokat, regionális és funkcionális intézményeket, szerveket is. Külön fejezetekben tárgyalja az ENSZ tevékenysége során felmerülö föbb kérdéseket, mint például a béke és biztonság, a gazdasági fejlődés, az emberi jogok, a nemzetközi jog, amelyek keretében ismerteti az egyes témákhoz kapcsolódó aktuális problémákat, megoldási mechanizmusokat, müködő szervezeteket. A kézikönyv elemzi e kérdéskörök nemzetközi szerződések általi védelmét, valamint az egyes fejezeteken belül teljes körüen bemutatja a nemzetközi szervezetek a kontinensek, illetöleg országok területén végzett tevékenységét. A kiadványon több helyen érezhető a fordítás színvonalának egyenetlensége. (P. A.)

- Nemzetközi jog

Kardos Gábor-Lattmann Tamás (szerk.)

(Sorozat: ELTE Jogi Kari Tankönyvek, ISSN 2060-6494; 3.)

ELTE Eötvös, Budapest, 2013

Tankönyv. Terjedelem: 494. Bibliográfia: 477-479. ISBN 9789633120224

- A 2010-es kiadás változatlan utánnyomása. (Sz. S.)

- Nukleáris jog a 21. század első évtizedeiben

KeCSkés Gábor-LAmm Vanda-SILYE Judit-Sulyok Gábor

CompLex, Budapest, 2013

Szakkönyv. Terjedelem: 177. Bibliográfia a lábjegyzetekben.

ISBN 9789632953397

- A kötet szerzői a Széchenyi István Egyetem Deák Ferenc Állam- és Jogtudományi Karának kutatói, oktatói. A könyv a nukleáris energia békés célú alkalmazásával és a nukleáris leszereléssel összefüggő kérdésekre vonatkozó nemzetközi szabályozást dolgozza fel, tudományos igénnyel, de egyben a mindennapi gyakorlat számára is hasznosítható módon. A szakkönyv hét fejezetben mutatja be többek között az 1960-as Párizsi és az 1963-as Bécsi Egyezmény felelösségi rendszerét, kísérletek egységes nukleáris kárfelelősségi szabályok létrehozására vonatkozó kísérleteket. A téma aktualitásához kétség sem fér, hiszen a közvélemény is sokat foglalkozik az iráni és az észak-koreai nukleáris fegyverkezéssel. A könyv megjelenését a Magyar Nukleáris Társaság támogatta. (P. N.)

- Európai gazdasági és politikai föderalizmus

MARJÁn Attila

Dialóg Campus, Budapest-Pécs, 2013

Monográfia. Terjedelem: 192. Bibliográfia: 187-192. ISBN 9786155376061

- A szerző a Budapesti Corvinus Egyetem habilitált doktora, 2010-ben megjelent Europe's Destiny c. könyvét beválasztották a legjobb akadémiai könyvek közé az Egyesült Államokban. Legújabb könyve a politikai és gazdasági föderalizmus elvi áttekintése mellett megvizsgálja Európa gazdasági és politikai föderalizálódásának előfeltételeit, akadályait, következményeit. A szerző áttekinti Németország válságkezelésben játszott szerepét, illetve a német-francia tengely az európai fö- 
deralizmushoz való viszonyát is. Részletesen elemzi a szorosabb gazdasági integráció irányába eddig tett intézkedéseket, valamint a politikai unióra vonatkozó elképzeléseket. A szerző részletesen kitér a politikai és gazdasági föderalizmus történeti fejlődésére, új irányvonalaira, a szabályozásra, a vonatkozó intézményi kérdésekre. Mindezeken túl átfogó elemzést nyújt a 2010-re kibontakozó pénzügyi és gazdasági válság kontextusára és hatásaira vonatkozóan is. (B. A.)

\section{- A nemzetközi jogi eredetű normák beépülése a magyar jogrendszerbe} Molnár Tamás (Sorozat: Institutiones Juris, ISSN 1218-9375, Dialóg Campus Szakkönyvek, ISSN 1417-7986)

Dialóg Campus-Dóm, Budapest-Pécs, 2013 Monográfia. Terjedelem: 303. Bibliográfia: 280-299. ISBN 9789639950894

- A szerző nemzetközi jogász, a Budapesti Corvinus Egyetem oktatója, monográfiája a PhD-értekezésének átdolgozott változata. A monográfia részletesen elemzi a nemzetközi jogi eredetủ normáknak az Alaptörvény által meghatározott magyar jogrendszerbe való beépülését. A könyv a nemzetközi jog és a magyar jog viszonyát elméleti szemszögből közelíti meg, majd a nemzetközi jog belső jogi megjelenítésének alkotmányos technikáival foglalkozik, amit a hazai nemzetközi szerződéskötési eljárás részletes elemzése követ. Külön fejezetek taglalják a nemzetközi szervezetek normatív határozatainak, Magyarország és más államok kifelé irányuló egyoldalú jognyilatkozatainak, illetve a nemzetközi bírói döntéseknek belső jogi helyzetét. A mű magas színvonalú, mély dogmatikai alapokkal, ugyanakkor számos ponton elöremutató javaslatokkal, így az a kutatók és a gyakorló jogászok mellett a külügyi apparátus, illetve más szaktárcák nemzetközi szerződésekkel dolgozó tisztviselői számára is hasznos lehet. (P. N.)

- Uniós szakpolitikák

Szabó Marcel-Láncos Petra Lea-Gyeney Laura (szerk.)

Szent István Társulat, Budapest, 2013

Tanulmánykötet. Bibliográfia a lábjegyzetekben. Terjedelem: 230. Második, átdolgozott kiadás. ISBN 9789632774602

- A szerkesztők a Pázmány Péter Katolikus Egyetem oktatói. Jelen kötet az azonos címmel 2012-ben megjelent mű második, átdolgozott kiadása. Az egyetemi oktatásban hasznosítható tanulmánykötet célja a közösségi politikák átfogó ismertetése. Ennek keretében bemutatásra kerülnek a szakpolitikák kialakításának hátterében meghúzódó érdekek és jogpolitikai megfontolások, valamint a politikák elsődleges jogi alapjai. A szerzők behatóan foglalkoznak az Európai Unió jogalanyiságának természetével, az európai közigazgatás rendszerével. Az Unió egyes szakpolitikáit pedig tematikus rendben mutatja be a könyv, ekképp külön az uniós alkotmányos jellegủ politikáit, az unió szabályozó jellegű politikáit, az elosztó jellegű politikákat és a sort az újraelosztó jellegủ politikák zárják. (Sz. Zs.) 
- A fegyveres összeütközések hatása a nemzetközi szerződésekre Szalal Anikó

Pólay Elemér Alapítvány, Szeged, 2013

(Sorozat: A Pólay Elemér Alapítvány Könyvtára, ISSN 1786-352X) Monográfia. Terjedelem: 194. Bibliográfia: 167-187. és a lábjegyzetekben. ISBN 9786155300073

- A szerző a Szegedi Tudományegyetem Állam- és Jogtudományi Karának oktatója. A kötet a szerző PhD-értekezésén alapul, melyben öt fejezetben mutatja be a fegyveres konfliktusok nemzetközi szerződésekre gyakorolt hatását. A mü nem csupán a téma elméleti alapjait és a hatályos szabályozást mutatja be részletesen, hanem az államok gyakorlatát is vizsgálja az I. világháborút lezáró békeszerződésektöl kezdődően. A szerző az 1969. évi bécsi egyezményt alapul véve eljárási javaslatokat dolgoz ki a szerződés felfüggesztését illetően arra az esetre, ha a nemzetközi fegyveres összeütközésben érintett államok nem akarják vagy nem tudják teljesíteni valamely szerződésüket. (K. Zs.)

- Az Országgyülés és az Európai Unió: törvények, határozatok Tamás Csaba Gergely-Szabó Gergely (szerk.)

Országgyülés Hivatala, Budapest, 2013

Kézikönyv. Terjedelem: 386. Bibliográfia: 307-386. ISBN 9789639848245

- A kötet negyedik, átdolgozott és bővített kiadása összegyűjti és rendszerezi az európai uniós tagsággal kapcsolatos országgyülési hatás-, illetve feladatköröket tartalmazó alaptörvényi, törvényi, illetve határozati rendelkezéseket azok indokolásával. Tartalmazza az Európai Unió alapító szerződéseinek legutóbbi módosításait kihirdető törvényeket, illetve a költségvetési paktumban Magyarország részvételét biztosító országgyülési határozatot, valamint az Országgyülés és a Kormány európai uniós ügyekben történő együttmüködését meghatározó rendelkezéseket. A függelék tartalmazza továbbá a Lisszaboni Szerződésnek a nemzeti parlamentekkel kapcsolatos rendelkezéseit is. A kötet hasznos segítségül szolgál az európai uniós ügyekkel foglalkozó politikusok, szakértők és az európai uniós tanulmányokat folytató hallgatók mellett mindazoknak, akik az Európai Unióval kapcsolatos jogalkotói tevékenység széles körü áttekintésében kívánnak szakmai segítséghez jutni. (B. A.)

- Az Európai Unió joga

VÁRnAY Ernő-PAPP Mónika

CompLex, Budapest, 2013

Tankönyv. Terjedelem: 1126. Bibliográfia: 1107-1126. ISBN 9789632950744

- A 2010-es kiadás változatlan utánnyomása. (Sz. S.)

- Európai kaleidoszkóp - Az Európai Unió és a kisebbségek

Vızı Balázs

(Sorozat: Föld-rész könyvek, ISSN 2060-5404)

L'Harmattan, Budapest, 2013

Monográfia. Bibliográfia a lábjegyzetekben. Terjedelem: 188. ISBN 9789632366531 
- A szerző a Nemzeti Közszolgálati Egyetem docense, a kisebbségi jogok elismert kutatója. A monográfia azt vizsgálja, hogy a nemzeti etnikai kisebbségek jogait mennyiben érinti az uniós jog, illetve az uniós intézmények milyen megközelítést alakítottak ki ebben a kérdésben. A szerző álláspontja szerint az Európai Unió jelentősen elmozdult az alapjogok védelmének irányába, melynek igazolását több tényezőben látja, így az Alapjogi Charta elfogadásában, az Alapjogi Ügynökség létrehozásában, továbbá az Unió csatlakozásában az Emberi Jogok Európai Egyezményéhez. Ebben a kialakulóban lévő védelmi hálóban kap helyet a kisebbségi jogvédelem is. Külön kiemelendő részei a monográfiának a romapolitikáról és a magyar státustörvényröl szóló fejezetek, melyek a szerző Leuveni Katolikus Egyetemen folytatott kutatásainak termékei. (Sz. Zs.)

\section{JOGTÖRTÉNET}

- Hagyomány és érték - Állam- és jogtudományi tanulmányok a Károli Gáspár Református Egyetem fennállásának 20. évfordulójára

Antalóczy Péter (szerk.)

Károli Gáspár Református Egyetem Állam- és Jogtudományi Kar, Budapest, 2013 Tanulmánykötet. Terjedelem: 370 . Bibliográfia a tanulmányok végén.

ISBN 9879639808508

- A szerzők a Károli Gáspár Református Egyetem Állam- és Jogtudományi Karának oktatói. A kötet az egyetem huszadik éves fennállásának kíván emléket állítani, s - a dékán szerkesztésében - tanszékekre tagolva tartalmazza az egyetem oktatóinak tanulmányait. A kötet összesen harmincegy munkát közöl, amelyek a legkülönbözőbb témákban íródtak nagyobbrészt magyar, kisebbrészt angol nyelven. A témák sokszínüsége miatt e kötet a jogtudományok bármely ágával foglalkozó szakember számára hasznos lehet. A gazdag lábjegyzetelés, illetve a böséges szakirodalom pedig további forrásként szolgálhat a tudomány művelői számára. (D. V.)

- Ünnepi kötet Dr. Blazovich László egyetemi tanár 70. születésnapjára Balogh Elemér-Homoki-Nagy Mária (szerk.)

SZTE ÁJTK, Szeged, 2013

(Sorozat: Acta Universitatis Szegediensis, ISSN 0324-6523)

Tanulmánykötet. Terjedelem: 776. Bibliográfia a lábjegyzetekben.

ISBN 9789633062364

- A szerzők többségükben egyetemi oktatók. A tanulmánykötet 57 különálló tanulmánnyal tiszteleg Blazovich László előtt, 70. születésnapja alkalmából. A tanulmányok a magyar, illetve egyetemes állam- és jogtörténet körében születtek. Igazodva az ünnepelt munkásságának szakmai kutatási súlypontjaihoz, többségében a középkori városi jogfejlödéshez, középkori büntetőjoghoz és közigazgatás-történethez kapcsolódó tanulmányokat olvashatunk. A kötet Nagy Katalin jóvoltából egy értékes bibliográfiával zárul, amely sorra veszi az ünnepelt több évtizedes munkásságát és publikációit, tudományos közléseit. (P. L.) 
- A’magyar Szent Koronának és az ahoz tartozó tárgyaknak históriája, mellyet sok régi és újjább irásokból ki jegyzett, rendbe szedett, meg világositott, 's kedves hazafiainak hasznokra közönségessé tett Decsy Sámuel

Decsy SÁmuel

Kossuth, Budapest, 2013 (hasonmás kiadás)

Monográfia. Terjedelem: 589. Bibliográfia a lábjegyzetekben.

ISBN 9789630976954

- A szerző 1782-1816 között élt társadalomtudós. A könyv az 1792-ben megjelent munkájának utánnyomása. A munka nem a Szent Korona-tant, hanem a szűkebb értelemben vett korona és koronázási jelvények történetét és jelentőségét mutatja be. A könyv négy részre tagolódik, amelyekben a szerző a korának megfelelő szellemiségben és tudományos igénnyel ismerteti a koronázás jelentőségét, és hangsúlyozza a korona és a nemzeti öntudat összefonódását. A munka alapjául az 1790:VI. törvénycikk szolgált, amely elrendelte a korona Magyarországon való tartását. A munka illeszkedik abba a 18. század végi tudományos közéleti hangulatba, amely megalapozta a reformkor szellemiségét. (P. L.)

- A római jog története és institúciói

FöLDI András-Hamza Gábor

18., átdolgozott és bővített kiadás, Nemzeti Tankönyvkiadó, Budapest, 2013

Egyetemi tankönyv. Terjedelem: XXXIX + 714. Mutatók: 669-712. Bibliográfia a lábjegyzetekben. ISBN 9789631975192

- Jász-Nagykun-Szolnok megye székházának és közigazgatásának története (18761990)

Fülöp Tamás (szerk.)

Magyar Nemzeti Levéltár Jász-Nagykun-Szolnok Megyei Levéltára, Szolnok, 2013 Forráskiadvány. Terjedelem: 488. Bibliográfia a lábjegyzetekben. ISBN 9789637244179

- A szerzők a Jász-Nagykun-Szolnok Megyei Levéltár dolgozói. A könyv teljes egészében - az addig még fel nem dolgozott - levéltári forrásokra épít. Folyamatos forrásmegjelölés mellett képekkel, alaprajzokkal, tervdokumentációkkal és közgyűlési jegyzőkönyvekkel alátámasztva - kronologikus sorrendben - eleveníti fel a szolnoki székház és az ahhoz kapcsolódó közigazgatás történetét a létrejöttétől a 20. századig, 1990-nel bezárólag. A könyv végén az alapul szolgáló levéltári források (elsősorban levelezések, határozatok, jegyzőkönyvek) is fellelhetőek, így a téma iránt érdeklődők akár a levéltárba való ellátogatás nélkül is megalapozott, hiteles információkhoz juthatnak a tárgykörben. (Sz. Zs.)

- Iura antiqua ac iura moderna mothodo comparativa investigata Opera selecta = Ausgewählte Schriften zur antiken Rechtsgeschichte, zur Rechtsvergleichung und zum geltenden Recht, Tom. III

HamzA, Gábor

Eötvös Univ. Verlag, Budapest, 2013

Tanulmánykötet. Terjedelem: 281. Bibliográfia és jegyzetek az egyes tanulmányok végén. ISBN 9789633121580 
- A szerző az ELTE egyetemi tanára, akinek életművéből 2013-ban már a harmadik gyüjteményes kötet látott napvilágot. Mint a korábbiak (az első kötet 2010-ben, a szerző 60. születésnapja tiszteletére jelent meg, a második kötet pedig 2011-ben - annotációját lásd: Pro Futuro 2013/2, 173), úgy ez is a professzor idegen nyelvű válogatott tanulmányainak tematikus füzére. E kötetböl is érezhető Hamza professzor kivételes szakmai tudása, széles körü müveltsége és tájékozottsága az antikvitástól a hatályos jogig. Az aktuális kötetben német, francia és olasz nyelvű történeti tanulmányokat találunk a római jog és annak továbbhatása köréböl. (B. J.)

- Kis magyar börtöntörténelem

HeInRICH-TAMÁsKa Péter

Unicus Mühely, Budapest, 2013

Monográfia. Terjedelem: 399. Bibliográfia: 383-384. ISBN 9786155084133

- A szerző diplomáját történelem szakos tanárként szerezte, majd levéltárosként dolgozott a Semmelweis Múzeumban, illetve az Országos Levéltárban is. Könyvében tizenkét országos börtönt mutat be azzal a céllal, hogy tételes és hiteles történelmi ismereteket népszerüsítő formában adjon közre. A szerző saját bevallása szerint szeret az „aktív pletyka” bünébe esni, ezért elsősorban nem másodlagos forrásokra, hanem saját börtönlátogatásaira, az ott lefolytatott beszélgetésekre, illetve az ott szerzett információkra támaszkodott műve megírása során. Számos fénykép mellett olyan ismert személyek történetei színesítik a könyvet, mint például Rózsa Sándor vagy Pipás Pista esete. (D. V.)

- A polgári peres eljárás történeti fejlődése Magyarországon: V. Szegedi Jogtörténeti Napok.

Homoki-Nagy Mária (szerk.)

Szegedi Tudományegyetem Állam- és Jogtudományi Kar, Szeged, 2012

Konferenciakötet. Terjedelem: 245. Bibliográfia a lábjegyzetekben.

ISBN 9789633062272

- A szerzők a 2011-ben Szegeden megtartott jogtörténész-konferencia résztvevői. Az ország valamennyi jogi karáról érkező kutatók összesen 18 tanulmányban emlékeztek meg a 19-20. századi perjogi kodifikáció előzményeiről és vívmányairól. A konferencia apropóját az 1911. évi I. törvénycikk megszületésének századik évfordulója adta, a tanulmánykötet azonban túlnőtte a konferencia eredeti célkitűzését. A szerzők a tágabb értelemben vett perjogi kodifikáció értelmében nemcsak az 1911. évi I. törvénycikkröl, hanem ahhoz kapcsolódóan a római jog perjogi alapelveiröl, a községi és választási bíráskodásról és a polgári perrendtartás alkotmánybírósági megítéléséről is értekeztek. (P. L.)

- Magánjogi jogesetek a bírói gyakorlat tükrében: adalék a magyar magánjog 18-19. századi történetéhez

HomokI-NAGY Mária lurisperitus Bt., Szeged, 2013

Monográfia. Terjedelem: 195. Bibliográfia: 195. ISBN 9789630870702 
- A szerző az SZTE ÁJTK Magyar Jogtörténeti Tanszékének tanszékvezető egyetemi tanára. A könyv a kodifikáció előtti magyar magánjog bemutatására törekszik, a helyi ítélkezési gyakorlat ismertetése alapján. A 19. századig a magyar magánjog meghatározó jogforrása Werbőczy Tripartituma, amely kétségtelenül egy pillanatfelvétel a 16. század elejei gazdasági, társadalmi viszonyokról, azonban a szokásjogi gyüjteményt még a 19. század közepén is alkalmazták. A szerző jogeseteken keresztül érzékelteti, hogy a közjog polgári átalakításához képest a magánjogi szabályok mennyivel lassabban változtak, s ugyanakkor kitér arra a sajátos belső jogfejlődésre, amely megakadályozta az idegen jog önkényes érvényesítését. A könyv szerkezeti felépítése a rendi magánjog jellegét tükrözi, elsösorban a vagyonjog körére fókuszál. A munka az egyetemi oktatásban kiegészítő tananyagként is hasznosítható. (P. L.)

- Geistiges Eigentum und Urheberrecht aus der historischen Perspektive Jakab Éva (Hg.)

Pólay Elemér Alapítvány, Szeged, 2013

(Sorozat: Lectiones luridicae, ISSN 2062-5588; 10)

Tanulmánykötet. Terjedelem: 159. Bibliográfia a lábjegyzetekben.

ISBN 9786155300196

- A kötet a Szegeden, 2012. május 17-19. között megrendezett nemzetközi konferencia utókiadványa, amely a Szegedi Egyetem sikeres TÁMOP-pályázatának támogatásával jelent meg. A benne foglalt 13 tanulmány angol, német és magyar nyelven a szellemi tulajdonhoz kapcsolódó jogi oltalmi formák speciális kérdéseit járja körbe, valóban történeti aspektusból. Képet kapunk az antik tulajdon- és dologfogalomról, a korai magyar szerzői, szabadalmi és védjegyjog szabályairól, egyes speciális, modern iparjogvédelmi és szerzői jogi eljárásokról, de a szellemi tulajdont célzó európai szabályozásról is. Az, hogy a szerkesztő a szerzők nevének ábécérendjébe szedte a tanulmányokat, és nem a tematikát vagy egy kronológiai rendet követett, a könyvet olvasók számára még színesebbé teszi a konferencián elhangzottakat. (B. J.)

- Humanizmus és jogtudomány: Brissonius szerződési formulái I.

JaKAB Éva

Pólay Elemér Alapítvány, Szeged, 2013

(Sorozat: Pólay Elemér Alapítvány, ISSN 1786-352X)

Monográfia. Terjedelem: 275. Bibliográfia: 265-275. ISBN 9786155300127

- Jakab Éva a Szegedi Tudományegyetem Állam- és Jogtudományi Karának tanszékvezető egyetemi tanára. A mű a római jog szerződési formuláinak bemutatására törekszik, Brissonius humanista jogtudós munkáin keresztül. Brissonius életútjának és munkájának ismertetését követően a formulákat egyes szerződési típusokon keresztül mutatja be a szerző, melyeken belül tovább differenciál. Az egyes szerződési modelleket gyakorlati példákon keresztül szemlélteti, amelyekhez fontosnak tartotta a kor gazdasági-társadalmi összefüggéseinek ismertetését is. (P. L.) 
- Egyetemes állam- és jogtörténet

KAJTÁR István

Dialóg Campus Kiadó, Budapest-Pécs, 2013

(4., átdolgozott és bővített kiadás)

(Sorozat: Institutiones Juris, ISSN 1218-9375; Dialóg Campus Tankönyvek, ISSN 1418-1274)

Egyetemi tankönyv. Terjedelem: 414. Bibliográfia: 222-236. ISBN 9789633121665

- A szerző a Pécsi Tudományegyetem professor emeritusa, akinek az Egyetemes állam- és jogtörténet fökollégium elsajátításához szükséges tankönyve a negyedik kiadását éri meg. A könyv érdekessége, hogy egyidejüleg, a Nordex Kft. gondozásában e-könyvként is megjelent, Herger Csabáné társszerzőségével, bővített kiadásban. A könyv ily módon könnyebben hozzáférhető, kereshető szövegü, e-könyv-olvasó nélkül (pdf-ben) is olvasható, modern kiadvány. (B. J.)

- Évszázadok mezsgyéjén: Négy magyar közigazgatás-tudós útkeresése és életpéldája

Kol Gyula

Nemzeti Közszolgálati Egyetem, Budapest, 2013

Monográfia. Terjedelem: 178. Bibliográfia a fejezetek végén.

ISBN 9786155344411

- A szerző a Nemzeti Közszolgálati Egyetem oktatója és a Magyar Tudományos Akadémia TK Jogtudományi Intézetének kutatója. Múvében négy jelentős, meghatározó 19-20. századi hazai közigazgatás-tudós, Zsoldos Ignác, Récsi Emil, Concha Győző és Magyary Zoltán életét, tudományos pályáját, valamint műveik jelentőségét tárgyalja egy-egy fejezetben. A szerző tehát életrajzzal vegyes tudományos pályaelemzést ad. A kötetet áttekinthető tagolás, több száz lábjegyzet és bőséges forrásjegyzék teszi igazán színvonalassá. Figyelemmel arra, hogy a mai közigazgatási és jogi felsőoktatásban a hangsúly elsősorban a köztörténetre, illetve az intézménytörténetre helyeződik, e mủ hiánypótló jellegü. (D. V.)

- A bizánci hatás kérdése a középkori magyar jogban és a magyarországi egyházjogban

KomÁROMı László

Pázmány Press, Budapest, 2013

(Sorozat: A Pázmány Péter Katolikus Egyetem Jog- és Államtudományi Karának Könyvei, Doktori értekezések, ISSN 2064-1907; 1.)

Monográfia. Terjedelem: 351. Bibliográfia: 287-339. és a lábjegyzetekben.

ISBN 9789633081082

- A könyv szerzője egyetemi oktató, könyve alapjául a Pázmány Péter Katolikus Egyetem Jog- és Államtudományi Karán 2008-ban sikeresen megvédett doktori értekezése szolgált. A szerző arra a kérdésre keresi a választ, hogy egyáltalán gyakorolt-e hatást a korai magyar joggyakorlatra a bizánci jogrendszer, és amenynyiben igen, akkor vajon milyen mértékben, és az miképp jelent meg. Sorra veszi a szóba jöhető közvetítő tényezőket és az ezek alátámasztására szolgáló bizánci 
és magyar jogforrásokat, mind a normák, mind pedig a szokásjog tekintetében. Így az összehasonlítás alapjául szolgáló oklevelek és történeti leírások adják a levont következtetések alapját az egyházjog, a magánjog és a büntetőjog területén is. A könyv forrásanyagát a szerző részben a frankfurti Max Planck-Institut für europäische Rechtsgeschichtében gyüjtötte, amikor Marie-Theres Fögen mellett kutathatott ösztöndíjasként. A könyv végén rövid angol nyelvű összefoglalás található. (Sz. Zs.)

- Jogtörténeti parerga: Ünnepi tanulmányok Mezey Barna 60. születésnapja tiszteletére

Máthé Gábor-Révész T. Mihály-Gosztonyi Gergely (szerk.)

ELTE Eötvös Kiadó, Budapest, 2013

Tanulmánykötet. Terjedelem: 408. Bibliográfia a lábjegyzetekben.

ISBN 9789633121665

- A szerzők a hazai jogtörténet művelői, akik meglepetésként, a szerkesztők által titokban tett felkérés alapján a születésnapon átnyújtott kötettel tisztelegtek az ELTE rektora és Magyar Jogtörténeti Tanszékének vezetője előtt. A kötet az ünnepelt munkásságához hol szorosabb, hol lazább szállal kapcsolódó kisebb írásokat, rövid tanulmányokat tartalmaz, amelyek között hangsúlyosan kapott helyet a büntetö- és büntetés-végrehajtási jog, az alkotmánytörténet és a jogi szimbólumkutatás is. De ezek mellett olyan különleges témák, mint a New York-i Magyar Menház vagy az Országos Nép- és Családvédelmi Alap müködésének bemutatása, a főnemesi házasságkötési szokások taglalása, az athéni tengeri háborúk története vagy a nemesi osztály elemzése teszik színessé a tanulmányok hosszú sorát. A kötet valóban szinte a teljes hazai jogtörténeti kutatási palettát átfogja, és e töredékek (azaz „parerga”) által a szakma méltón tiszteleg a hatvanadik születésnapját ünneplő Mezey Barna előtt. (B. J.)

- Név és jog: a névviselés jogi szabályozásának fejlődése Magyarországon

MEgYERI-PÁLFFI Zoltán

Gondolat, Budapest, 2013

(Sorozat: Dignitas luris, Debreceni Iskola, ISSN 2063-5087; 12)

Monográfia. Terjedelem: 296. Bibliográfia: 255-269, forrásjegyzék: 271-279. ISBN 9789636934996

- A szerző debreceni egyetemi adjunktus, aki 2012-ben védte meg a kötet alapjául szolgáló disszertációját. A hazai jogtörténeti kutatások szemléletétől és módszereitől sokban különböző, Nyugat-Európa műhelyeiben azonban jól ismert utat választott: tudatosan vállalt, és a kritika ellenére is követett célkitüzése volt a névviselés kapcsán a társadalmi, politikai, nyelvi, közigazgatási (szervezeti) stb. aspektusokat részletesen, komplexen elemezni, a legkülönbözőbb eredményeket, hatásokat egyfajta lineáris, kronológiai rendben összefoglalni, és mindezeket a jogrendszer számos ágára a teljesség igényével kiterjesztő kontextusba állítani. E körben számos tudományág eredményeire tudott támaszkodni, és a könyv ezek határterületein mozog. A feldolgozás szokatlanul sokszínű forrásbázison épül fel. A komplex feldolgozás miatt a dolgozatból a klasszikus szemléletmód szerinti ré- 
szeket hiányolhat, másokat esetleg oda nem illönek tarthat az olvasó, a könyv mégis tartalmas, újszerü, komoly kutatási eredményeket felmutató, és gazdagítja a hazai jogtudományt. (B. J.)

- A fenyítöházak forradalma: a modern büntetés-végrehajtás alapvetése Európában MeZEY Barna

Gondolat, Budapest, 2013

Monográfia. Terjedelem: 540. Bibliográfia: 453-478. és a lábjegyzetekben. ISBN 9789636934880

- A könyv a 2012-es első kiadás változatlan utánnyomása. Annotációját lásd a Pro Futuro 2014/2. számában.

- Ius criminale Romanum - Tanulmányok a római jog köréböl MOLNÁR Imre

Pólay Elemér Alapítvány, Szeged, 2013

(Sorozat: A Pólay Elemér Alapítvány Könyvtára, ISSN 1786-352X; 45.)

Tanulmánykötet. Terjedelem: 255. Bibliográfia a lábjegyzetekben. ISBN 9786155300097

- A szerző a római jogot oktató szegedi professor emeritus. A kötet a korábbi magyar és német nyelven megjelent, büntetöjogi tárgyú tanulmányait tartalmazza. A tanulmányokban a szerző arra keresi a választ, hogy a római kori büntetőjog és büntetőjogi alapelvek ugyanolyan hatással vannak-e a mai jogrendszerünkre, ahogy az a magánjog területén egyértelműen megfigyelhető. Az egyes tanulmányokban sorra vizsgálja a különböző római jogi büntetőjogi alapelveket, néhány büntetőjogi alapfogalmat, magát a büntetési rendszert, és kiemel bizonyos büncselekményeket, tényállásokat is, vizsgálatait folyamatosan autentikus forrásokkal alátámasztva. A tanulmányok végén magyar, és néhol német nyelvű összefoglaló is található, így azok kiváló alapul szolgálhatnak hasonló tárgyú jog-összehasonlító dolgozatokhoz. (Sz. Zs.)

- A locatio conductio a klasszikus kori római jogban

MOLNÁR Imre

Pólay Elemér Alapítvány, Szeged, 2013

(Sorozat: A Pólay Elemér Alapítvány Könyvtára, ISSN 1786-352X; 44)

Monográfia. Terjedelem: 197. Bibliográfia: 189-197. ISBN 9786155300080

- A szerző a Szegedi Tudományegyetem emeritus professzora, aki a jelen könyv alapjául szolgáló dolgozattal évtizedekkel ezelőtt szerezte meg az állam- és jogtudományok kandidátusa fokozatot. E müve anyagi okok miatt sokáig csak kisebb tanulmányok formájában látott napvilágot, most a maga egészében pályázati támogatásnak köszönhetően jelenhetett meg. Az időtáló tanulmány a klasszikus kori locatio conductio kifejtését tűzi ki célul, nem mellőzve annak történeti áttekintését sem. Kimerítő részletességgel ismerteti a jogviszony alanyait, a rájuk vonatkozó felelösségi és veszélyviselési szabályokat, továbbá a jogviszony tárgyát és tartalmát a locatio conductio rei, a locatio conductio operarum, illetve a locatio conductio operis vonatkozásában is. A munka színvonalát emeli a több száz hivatkozás, valamint a felhasznált tetemes hazai és külföldi szakirodalom. (D. V.) 
- Fekete László, a tudós közjegyző

RoKolya Gábor

Magyar Országos Közjegyzői Kamara, Budapest, 2013

Monográfia. Terjedelem: 252. Bibliográfia: 239-248. ISBN 9789638979001

- A szerző a közjegyzőség múltjának kutatása iránt elkötelezett gyakorló közjegyző, aki korábban már átfogó monográfiával szolgált a tudománytörténetnek. Jelen könyvében az 1949-ig létezett királyi közjegyzőség egy kiemelkedő, a gyakorlati munkásságot a tudományos tevékenységgel ötvöző alakjának életrajzát dolgozza fel. A biográfia azonban csak eszköz: e kivételes személyiségen keresztül az egész korszak társadalomtörténetéről, az értelmiségi középosztály szellemiségéről, életmódjáról és életfelfogásáról kapunk plasztikus képet rengeteg fényképfelvétellel, dokumentummal illusztrálva. Az olvasmányos stílusú könyv szinte elrepíti az olvasót a Királyi Közjegyzők Közlönye főszerkesztőjének mindennapjaiba, akit 1949-ben eltávolítottak a pályáról: az új szemléletű közjegyzői karban már nem volt helye. A könyv az életpálya tudományos igényü, elemző feldolgozását nyújtja, ám azt közérthető, rendkívül igényes, reprezentatív formába öltözteti. (B. J.)

- Európai jog-és alkotmánytörténelem

Ruszoly József

Opera lurisprudentiae 1.

Pólay Elemér Alapítvány, Szeged, 2013

Egyetemi tankönyv, kézikönyv. Terjedelem: 712. Bibliográfia: 651-652. és a lábjegyzetekben. Mutatók: 653-663 (személyi), 664-670 (történetföldrajzi), 671-707 (tárgymutató). ISBN 9789639650787

- A könyv a 2011-es első kiadás változatlan utánnyomása.

- Szemelvények a tiszti ügyészek feladataiból

SzENDREI Géza

Legfőbb Ügyészség, Budapest, 2013

Kismonográfia, forráskiadás. Terjedelem: 112. Bibliográfia: 651-652. és a lábjegyzetekben. ISBN 9789639650787

- A mü 2012-ben változatlan formában megjelent egy másik kiadónál. Annotációját lásd a Pro Futuro 2014/2. számában.

- $A$ „jelképes” császárság alkotmánya: fejezetek a japán alkotmánytörténet köréből TAmÁs Csaba Gergely

Pázmány Press, PPKE JÁK, Budapest, 2013

(Sorozat: A Pázmány Péter Katolikus Egyetem Jog- és Államtudományi Karának Könyvei. Doktori értekezések 2. ISSN 2064-1907; 2)

Monográfia. Terjedelem: 188. Bibliográfia: 175-188. ISBN 9789633081099

- A szerző a Pázmány Péter Katolikus Egyetem Jogtörténeti Tanszékén Szabó István doktoranduszaként készítette el és védte meg a kötet alapjául szolgáló diszszertációját (2012). A Kállay István által megkezdett úton haladva, saját korábbi TDK-eredményeire, személyes szakmai kapcsolataira és Japánban szerzett ismereteire is támaszkodva hiánypótló alkotmánytörténeti munkát írt, hiszen a 19. század második felétől a 20. század közepéig tartó korszakok (Meiji- és a Shōwa- 
korszak) japán alkotmányosságáról meglehetősen kevés elemző bemutatás áll rendelkezésre magyar nyelven. Bemutatja a porosz mintára készült, demokratikus Meiji-alkotmány keletkezéstörténetét, föbb jellemzőit, majd kitér a demokrácia fokozatos felszámolására, a második világháború alkotmányos hatásaira, végül ismerteti az erősen amerikai hatásra készült Shōwa-alkotmány jellegadó sajátosságait. A könyvet jól használhatóvá teszi a japán szójegyzet, valamint a nagyobb nehézség nélkül, angol, illetve német nyelven hozzáférhető tekintélyes bibliográfia. (B. J.)

- A hódmezővásárhelyi föispánság története 1873-1950 VARSÁNYI Attila Magyar Nemzeti Levéltár Csongrád Megyei Levéltára, Szeged, 2013 (Sorozat: Tanulmányok Csongrád Megye Történetéből, ISSN 0133 414X; 11) Monográfia. Terjedelem: 313. Bibliográfia a lábjegyzetekben. ISBN 9789637237867

- A szerző 2011-ben szerzett PhD-fokozatot, a könyve alapjául az akkor megvédett doktori értekezés szolgál. A 19-20. századi törvényhatósági rendszer feldolgozása és kutatása a mai napig kedvelt téma a történészek és jogtörténészek között egyaránt. A munka módszere nem jog-, hanem köztörténeti jellegű, hiszen levéltári forrásokra támaszkodva mutatja be Hódmezővásárhely főispánságát, elsősorban a korszak történelmi, köztörténeti viszonyai alapján. Sajátossága, hogy kiemelt hangsúlyt fordít a föispánok személyére, életútjára, és ez a könyv szerkezeti felépítésében is visszaköszön. (P. L.)

- A XII táblától a 12 ponton át a magánjog új törvénykönyvéig

ZLINSZKY János

Szent István Társulat, Budapest, 2013

Tanulmánykötet. Terjedelem: 778. Bibliográfia a lábjegyzetekben.

ISBN 9789632774626

- A szerző a hazai jogtudomány kiemelkedő, 2015 nyarán elhunyt alakja, akit a római jogtól a hatályos alkotmányjogig és a tételes jogokig a jogtudomány minden területét átfogó enciklopédikus tudása a politikai okokból parkolópályára kényszerített ipari munkásból az alkotmánybírói székbe emelt. E könyve (amelynek szerkesztésében korábbi tanítványai közremüködtek) tulajdonképpen életmü-öszszefoglalás, amely majd 70 év gondolatainak reprezentatív metszete. Zlinszky professzor számos nyelven és közlöhelyen (sokszor külföldön) megjelent munkáinak olyan gyüjteménye szerepel e könyvben, amelyek ma már eredetiben nehezen hozzáférhetők, így újrakiadásuk a jelenkori hazai felhasználást könnyíti. A tanulmányok kisebb része pedig valódi kuriózum: mindeddig kéziratban maradt munkák első közlése. Tematikáját tekintve a kötet római jogi, magyar jogtörténeti, polgári jogi és a jogászi etikával foglalkozó tanulmányokat fog méltó keretbe. (B. J.) 


\section{KÖZIGAZGATÁSI JOG}

- Közszolgálat - Integritás és etika

Bencsik András (szerk.)

Jövő Közigazgatásáért Alapítvány, Pécs, 2013

(Sorozat: Pécsi Közigazgatás-tudományi Közlemények, ISSN 2061-7119; 4.)

Konferenciakötet. Terjedelem: 107. Bibliográfia a lábjegyzetekben.

ISBN 9789638875525

- A szerkesztő egyetemi oktató, a szerzők elméleti és gyakorlati szakemberek. A kötet a Pécsi Tudományegyetem Állam- és Jogtudományi Karán 2012-ben megrendezett „Közszolgálat - Integritás és etika” címü konferencia előadásainak szerkesztett változata. A kérdéskörnek különleges aktualitást adott, hogy az állami/ önkormányzati alkalmazásban álló tisztviselői kör jogi szabályozása 2011-ben jelentősen átalakult. A munka összetettsége jól érzékelteti a választott téma sokszínüségét. A feldolgozott területek között éppúgy megtalálni az etikával és erkölccsel általában foglalkozó előadásokat, mint a közszolgálat fejlődésére vonatkozó legfontosabb elképzeléseket, valamint a korrupciós kockázatokra rávilágító munkákat. (Ba. A.)

- Államtan és a magyar állam szervezete

Patyi András-Téglási András (szerk.)

Nemzeti Közszolgálati és Tankönyv Kiadó, Budapest, 2013

Tankönyv. Terjedelem: 344. Bibliográfia a fejezetek végén.

ISBN 9786155344299

- A kötet szerzői egyetemi oktatók. Az államtudományi és jogi képzések elengedhetetlen része napjainkban, hogy megismertessék a hallgatókkal az államra, valamint az államhatalomra vonatkozó legalapvetőbb elméleteket, továbbá bemutassák az állami szervek rendszerét. A tankönyvben az áttekintés központi elemét nem pusztán a különböző hatalmi ágak és az azokhoz tartozó szervek feladatainak bemutatása adja, hanem az egymással összefüggő kapcsolatrendszerek érzékeltetése. A munka kiemelten foglalkozik az államszervezet felépítésének legfontosabb alkotmányos elveivel. (Ba. A.)

- Közigazgatási jog. Általános rész III.

Fazekas Marianna (szerk.)

ELTE Eötvös, Budapest, 2013

Tankönyv. Terjedelem: 346. Bibliográfia a fejezetek végén.

ISBN 9789633121771

- A szerzők egyetemi oktatók. Céljuk, hogy a közigazgatási joghoz kapcsolódóan a dogmatikai alapokat és nemzetközi összehasonlító ismereteket is közvetítsenek. A tankönyv a közigazgatási jog elméleti kérdésein belül különösen a közigazgatási szankcióra fókuszál. A kötet bemutatja a közigazgatási jog helyét a jogrendszerben, a közigazgatási jog forrásait, a jogi normákat és a közigazgatási jogviszonyok jellemzőit. A szankciórendszer vizsgálatánál részletesen szól a szabálysértési jogról és az európai hatásokról a közigazgatási eljárásjogban. (V. B.) 
- A közigazgatási hatósági eljárás és szolgáltatás általános szabályai Balla Zoltán (et al.) Negyedik, átdolgozott kiadás. Rejtjel Kiadó, Budapest, 2013 Tankönyv. Terjedelem: 434. Bibliográfia: 433-434. ISBN 9789637255861

- A szerzők egyetemi oktatók. A tankönyv 2013. évi kiadása bemutatja a közigazgatási hatósági eljárási jog fejlődését, figyelemmel a 2012-es változásokra, és a könnyebb érthetőség kedvéért követve a Ket. felépítését. Az egyes részfejezeteken belül megismétli a törvény szövegét, majd a vonatkozó részeket magyarázzák a szerzők. A tananyag elsajátítása érdekében tárgyszavakat tartalmaz a lap szélén a lényegkiemelés végett. ( $V$. B.)

- Kommentár az önkormányzati törvényhez

FÁBIÁn Adrián CompLex, Budapest, 2013

Kommentár. Terjedelem: 386. Bibliográfia a föszövegben. ISBN 9789632952406

- A szerző egyetemi oktató. A kommentár bevezető fejezete a magyar helyi közigazgatás történetével, az önkormányzatokra vonatkozó, az Alkotmányban és az Alaptörvényben található szabályokkal, illetve a Helyi Önkormányzatok Európai Chartájával foglalkozik. Ezt követően a Magyarország helyi önkormányzatairól szóló 2011. évi CLXXXIX. törvény rendelkezéseit veszi sorra hét fejezetben. A kötet a szerző szándéka szerint elsősorban az önkormányzatok tisztségviselöi, a helyi képviselök és más gyakorlati szakemberek számára nyújt segítséget a törvény megismerésében, értelmezésében, valamint alkalmazásában, összevetve azt a korábbi szabályozással is. Azon túl, hogy tartalmazza az egyes szakaszok magyarázatát, rávilágít az eddig felmerült problémás kérdésekre is, több helyen megoldási javaslatokat kínálva. Külön érdeme, hogy kiemeli a kapcsolódó joggyakorlatot és jogszabályokat. (P. O.)

- Európai közigazgatás

Torma András (szerk.) Miskolci Egyetemi Kiadó, Miskolc, 2013

Tankönyv. Terjedelem: 257. Bibliográfia: 251-257. ISBN 9786155216350 A 2012-es kiadás változatlan utánnyomása. (P. O.)

\section{MUNKAJOG}

- Bevezetés a társadalombiztositási jogba Hajdú József-Homicskó Árpád Olivér (szerk.)

(Sorozat: Bethlen-sorozat, ISSN 2062-2546)

Patrocinium, Budapest, 2013

Egyetemi jegyzet. Terjedelem: 171. Bibliográfia: 168. és a lábjegyzetekben. ISBN 9786155337048

- A szerzők és szerkesztők a munka- és szociális jog területén tevékenykedő oktatók és gyakorló jogászok. Könyvüket kifejezetten egyetemi hallgatóknak szánják, 
hogy ezzel is segítsék őket a társadalombiztosítási és szociális jog jobb megértésében. A szociális jog elméleti alapjainak tárgyalásával kezdődik a kötet, amit a hazai társadalombiztosítási jog történetével, a társadalombiztosítási jog alapjaival, összefüggéseivel, müködésével foglalkozó fejezetek követnek. Végül bemutatásra kerülnek a szociális jog nemzetközi és uniós vonatkozásai, valamint a szociális biztonsági rendszerek koordinációjának uniós szabályanyaga. A szerzők a jogszabályok 2013. április 1-jén hatályos állapota alapján állították össze a jegyzetet. (B. K.)

- Szociális jog I. - Európai és magyar foglalkoztatás támogatási és munkaügyi, valamint munkavédelmi igazgatási jog

JAKAB Nóra-RÁcz Zoltán-Prugberger Tamás

Bíbor, Miskolc, 2013

Egyetemi tankönyv. Terjedelem: 150. Bibliográfia nincs. ISBN 9789639988804

- A szerzők egyetemi oktatók és gyakorló jogászok. A kötet a szociális jog körébe tartozó témaköröket dolgoz fel, azon belül is elsősorban a foglalkoztatáspolitika rendszerét, amelynek keretében ismertetésre kerülnek az adott témához tartozó, 2013 novemberében hatályos jogszabályok is. A szerzők kötetükben bemutatják a foglalkoztatás támogatásával kapcsolatos jogintézményeket és jogszabályi hátteret. Elemzésre kerülnek az egyes aktív és passzív foglalkoztatáspolitikai eszközök, a segélyezés rendszere, valamint a munkanélküliség csökkentését elősegítő egyes foglalkoztatási formák. Mindezeken túl a szerzők megvizsgálják a vonatkozó uniós rendelkezéseket, a foglalkoztatáspolitika terén végbement jogharmonizációt, valamint a közép-kelet-európai szabályozási formákat. (B. K.)

- A szociális segély csökkentésének hatásai a vidéki Magyarországon - The effects of reducing the social allowance in rural Hungary

Nagy Katalin (szerk.)

Pro Cserehát Egyesület, Budapest, 2013

Tanulmánykötet. Terjedelem: 131. Bibliográfia az egyes fejezetek végén. ISBN 9789630873345

- A tanulmányok szerzői elméleti és gyakorlati szakemberek, illetve oktatók. A kötet a szociális igazgatásról és szociális ellátásokról szóló 1993. évi III. törvény 2012. január 1-jén hatályba lépett módosításaira reflektál. E módosítások következtében csökkent a foglalkoztatást helyettesítő támogatás összege és folyósításának feltételei is szigorodtak. A szerzők mindezek azonnali és elhúzódó társadalmi következményeit vizsgálják, összevetve a törvénymódosítást a nemzetközi szociális normákkal, de kitérve a változás szociálpszichológiai, antropológiai és szociológiai aspektusaira is. A tanulmányokat a vizsgálat során készített interjúk egy-egy részlete, illetve számos kép egészíti ki, érzékeltetve a társadalom peremén élö, munkanélküli emberek kilátástalan helyzetét. A kötet angol és magyar nyelven készült. (B. M.) 
- Munkahelyi követelmények A-tól Z-ig - Gyakorlati tanácsadó a biztonságos és az egészséget nem veszélyeztető munkahelyek megteremtéséhez Nemeskey Károly-Varga László (szerk.)

Dashöfer, Budapest, 2013

Szakkönyv. Terjedelem: cserélhető lapok. Bibliográfia a fejezetek végén. ISBN 9639313009

- A szerzők és szerkesztők a munkavédelem területén jártas szakemberek. A kapcsos formában 2000-ben kiadott könyv a jogszabályi változások következtében több alkalommal aktualizálásra került, utoljára 2013-ban. A háromkötetes mü az egyes (veszélyes) technológiák biztonsági követelményeit, a munkavédelem technikai előirásait és jogszabályi rendelkezéseit mutatja be. A szerzők így elsősorban a munkáltatók és a munkavédelmi szakemberek számára kívánnak gyakorlati útmutatót biztosítani, hogy a jogszabályi követelményeknek megfelelő, biztonságos és egészséget nem veszélyeztető munkakörülményeket tudjanak kialakítani. Az egyes fejezetek végén a témakörhöz kapcsolódó fontosabb jogszabályok és szabványok jegyzéke, valamint irodalomjegyzék található. (B. K.)

- A foglalkoztatás elősegítés és igazgatás joga

Prugberger Tamás-Jakab Nóra

Bíbor, Miskolc, 2013

Egyetemi jegyzet. Terjedelem: 182. Bibliográfia a jegyzetekben.

ISBN 9789639988798

- A szerzők egyetemi oktatók. A kötet a 2011-es kiadás hatályosított és bővített változata, amit a foglalkoztatáspolitika szabályainak 2011-ben bekövetkezett jelentős változásai indokoltak. A szerzők bemutatják a foglalkoztatáspolitika nemzetközi, uniós és hazai jogforrásait és szabályait, közigazgatás-szervezeti rendszerét, az aktív és passzív foglalkoztatáspolitikai eszközöket, valamint a közép-kelet-európai államoknak a foglalkoztatást elősegítő szabályrendszerét. Mindezeken túl pedig elemzésre kerülnek az előző kötet kiadása óta bekövetkezett jogszabályi változások. (B. K.)

\section{- Az emberierőforrás-menedzsment alapjai}

Roóz József

BGF Perfekt, Budapest, 2013

Tankönyv. Terjedelem: 317. Bibliográfia a fejezetek végén és a lábjegyzetekben. ISBN 9789633946701

- A szerző főiskolai oktató. A kötet célja, hogy megkönnyítse az egyetemi hallgatók számára az emberierőforrás-menedzsment alapjainak elsajátítását. Az első rész elhelyezi az emberi erőforrást a munka világában. A második fejezet az emberierőforrás-menedzsment környezetével, így a munkaerőpiac jellemzőivel és struktúrájával, valamint a munkaügyi kapcsolatok hazai és uniós szabályaival foglalkozik. Az utolsó rész az alkalmazott emberierőforrás-menedzsmentről szól, így többek között a teljesítményértékelésröl, az ösztönzésmenedzsmentröl, illetve a személyügyi feladatok ellátásáról. (B. K.) 
- Biztonság és egészségvédelem a változó munkahelyeken

Szakmáry Éva-Ungváry György-Walz Géza (szerk.)

Nemzeti Munkaügyi Hivatal, Budapest, 2013

Tankönyv. Terjedelem: 120. Bibliográfia a fejezetek végén. ISBN nincs.

- Aszerkesztők munkavédelmi, munkaegészségügyi szakemberek. A kötet azon tevékenységekre vonatkozó munkavédelmi követelményeket mutatja be, amelyek esetében a veszélyeztetések gyakorisága és a szabálytalanságok jellege alapján a munkakörülmények fokozottabb ellenőrzése szükséges. Ennek megfelelően a könyv kiemelten tárgyalja az építési munkahelyeket, az ipari alpintechnikát, valamint a mezőgazdasági és erdészeti tevékenységet, de említésre kerül a képernyő előtti munkavégzés, illetve a mélyszíni bányászat, továbbá az egészségügy és a közlekedés területén figyelembe veendő munkahigiénés követelmények is. A tartalom megértéséhez számos kép és táblázat nyújt segítséget. (B. M.)

- Alapvető munkaegészségügyi ismeretek Ungváry György-Szakmáry Éva-Walz Géza (szerk.)

A Il. kötet szerkesztésében Walz Géza nem vett részt.

Nemzeti Munkaügyi Hivatal, Budapest, 2013

Tankönyv. Terjedelem: Elméleti alapok I. 82.; Elméleti alapok II. 102. Bibliográfia a fejezetek végén. ISBN nincs.

- A szerkesztők munkavédelmi, munkaegészségügyi szakemberek. Az első kötet a kémiai biztonság munkahelyeken történő kialakítását célozza, míg a második a munkahelyeken előforduló különböző kóroki tényezőket ismerteti. Az első kötet a kémiai biztonságba való bevezetés és az ezzel kapcsolatos hazai és uniós szabályozás bemutatását követően több fejezetben is tárgyalja például a veszélyes anyagok osztályozását, valamint az ezekkel kapcsolatos munkavédelmi felügyelői feladatokat. A második kötet négy fejezete a fizikai, biológiai, ergonómiai és pszichoszociális kóroki tényezőkre fókuszál, azonban az első kötethez hasonlóan minden fejezetben kifejezetten említésre kerülnek a munkavédelmi felügyelők által e téren megvalósítandó feladatok. (B. M.)

\section{PÉNZÜGYI JOG ÉS KÖZMENEDZSMENT}

- Az urbanizáció általános elmélete

Cerdá, Ildefonso

Scolar Kiadó, Budapest, 2013

Monográfia. Terjedelem: 238. Bibliográfia: 236-238. ISBN 9789632444963

- A szerző a XIX. század újító spanyol várostervezője, akinek munkásságát Antonio Lopez de Aberasturi ismerteti. A kiadvány két nagy részből áll. Az első Cerdá életét és életművét mutatja be, míg a második négy részre bontott, melyekben a szerző urbanizációval kapcsolatos elméleti elgondolásai és gyakorlati tapasztalatai kaptak helyet, melyeket Barcelona városának példáján szemléltet a szerző. Az urbanizáció kapcsán megismerhetjük Cerdá urbanizációs elméletét, arra vonat- 
kozó téziseit, hogy miért is kell az urbanizációt külön tudományterületként kezelni, milyen alapelveknek kell érvényesülniük a tökéletes urbanizáció során, és azok hogyan ültethetők át a gyakorlati életbe. (V. J.)

- Jog - Régiók - Fejlesztés

Drinóczi Tímea-Novák Barnabás (szerk.)

Pécsi Tudományegyetem Állam- és Jogtudományi Kara - Eszéki J. J. Strossmayer Egyetem Állam- és Jogtudományi Kara, Pécs-Eszék, 2013

Konferenciakötet. Terjedelem: 627. Bibliográfia a lábjegyzetekben.

ISBN 9789536072781

- A szerzők a Pécsi és az Eszéki Egyetem Állam- és Jogtudományi Karának oktatói. A kötet a DUNICOP projekt keretében Pécsett, 2013. július 14-15. között megrendezésre kerülő „Law - Regions - Development. Legal implications of local and regional development" címú nemzetközi konferencia eredményeit összegzi. Jelen kötet, a pécsi és az eszéki jogi kar közötti együttmüködés harmadik kiadványa. A konferenciakötet öt fejezetből áll és 24, többnyire többszerzős, horvát-magyar tanulmány található benne. Az első három fejezet a regionális kormányzással (regionális fejlesztés, helyi önkormányzatok, történeti megközelítés) foglalkozik, a negyedik a környezetvédelemmel, az ötödik fejezet pedig a regionális fejlesztés és a környezetvédelem speciális területeit vizsgálja. A kötet magyarul, angolul és horvátul is megjelent. (B. Á.)

- A számvitel és az adózás aktuális kérdései 2013

FELlegı Miklós-Füredi-FülöP Judit-Kardos Barbara-Kántor Béla-MusinszKI Zoltán- PÁL Tibor-PÁL Tiborné-SıKLósı Ágnes-TótH Zsuzsanna-VÁRKonYINÉ JuHÁSZ Mária- Veress Attila

Reálszisztéma Dabasi Nyomda Zrt., Budapest, 2013

Kézikönyv/tankönyv. Terjedelem: 256. Bibliográfia nincs. ISBN 9789638978905

- A szerzők gyakorlati szakemberek. A kiadvány első részében a számvitelt érintő lényegi változások és újdonságok bemutatására törekszik. Az olvasók megismerhetik a számviteli törvény akkor megváltozott rendelkezéseit, a mikrogazdálkodói egyszerüsített éves beszámolóra, az ellenőrzésre és önellenőrzésre, az egyes követelések, készletek számviteli elszámolására vonatkozó előírásokat. A mü második egységében egyrészt a 2013-ban aktuális adó-, illeték- és járulékszabályok változásai, illetve az akkor bevezetett új adónemekre vonatkozó esettanulmányok lelhetők fel. Az ismeretek elsajátítását gyakorlati példák és feladatok segítik, melyekhez a szerzők megoldó kulcsot is mellékeltek. (V. J.)

- Adóharmonizáció. Az adózás Európában - VII. Nemzetközi Adókonferencia elöadásainak anyagaiból készült tanulmányok 2013

HERICH György (szerk.)

Penta Unió, Pécs, 2013

Tanulmánykötet. Terjedelem: 232. Bibliográfia nincs. ISBN 9786155249105

- A kötet a VII. Nemzetközi Adókonferencia azon tanulmányait foglalja össze, melyek az európai adóharmonizáció kérdését vizsgálják. A szerzők az elemzett terü- 
letek legtekintélyesebb szakemberei, akik nemcsak a hatályos joganyag bemutatását végzik el, hanem elemzik az egyes területek harmonizációs folyamatait és gyakorlati tapasztalatait, így különösen az Európai Bíróság döntéseit. Az egyes adónemek, mint a társasági adó, személyi jövedelemadó, fogyasztási adó, jövedéki adó és ezek adóigazgatási területeinek bemutatása mellett a könyv jogelméleti, közgazdasági kérdéseket is vizsgál. Nem maradt ki az elemzésből a szociális rendszer, a vámok és támogatások rendszere sem. A helyzetkép bemutatását követően a közeljövőben várható lépések, tendenciák is felsorakoztatásra kerülnek. A kötet nemcsak az adószakértőknek, hanem a jogalkalmazás, a jogszabályelökészítés és a jogértelmezés területén dolgozó szakembereknek is segítséget nyújthat a napi munkájuk során. (B. P.)

- Adózás Európában: Ausztria, Ciprus, Horvátország, Magyarország, Románia, Szlovákia

HERICH György (szerk.)

Penta Unió, Pécs, 2013

Szakkönyv. Terjedelem: 232. Bibliográfia nincs. ISBN 9786155249099

- A szerzők magyar nyelven beszélő, hazájukban elismert adószakértők. A könyv a hetedik magyarországi Nemzetközi Adókonferencia előadásainak anyagából készült. Az Európai Unió bővülése, a határokon átnyúló vállalkozási lehetőségek és a globális hatások miatt fontos a szomszédos országok adórendszereinek ismerete. Az egyes tanulmányok az érintett országok adórendszereit elemzik részletesen. Ez nemcsak az adótervezéshez, hanem a székhelyet kereső vállalkozásoknak is eligazodást nyújt. A könyv végén összehasonlító adatsorokat, táblázatokat találunk, melyek által összevethetővé válnak az egyes adórendszerek. A szakkönyv mind az adópolitika kidolgozásában részt vevők, mind a gyakorlatban tevékenykedő külföldi és belföldi szakemberek számára hasznos. (B. P.)

- Pénzügy III.: államháztartási és adózási ismeretek a PM pénzügyi-számviteli és vállalkozási ügyintéző szakképesités számára

HORVÁTH Zsuzsanna

Nemzedékek Tudása, Budapest, 2013

Tankönyv. Terjedelem: 187. Bibliográfia: 182-183. ISBN 9789631967722

- A könyv a pénzügyi-számviteli és vállalkozási ügyintéző szakképesítés számára készített pénzügyi feladatok követelménymodul harmadik részegysége, amely a legfontosabb államháztartási és adózási ismereteket tartalmazza. Bemutatásra kerül a magyar államháztartás rendszere, az Európai Unió költségvetése, a legfontosabb adónemek és a hazai társadalombiztosítási rendszer. Számtalan ábra, adatsor és táblázat szemlélteti az írottakat. Az elméleti ismeretek megértését kidolgozott példák segítik. A fejezetek végén feladatok is helyet kaptak, melyek megoldása - a szerző célja szerint - önálló vagy csoportos kutatómunkára serkentheti a tanulmányozót. A könyvet fogalomtár zárja. (B. P.) 
- Közpénzügyek és államháztartástan

LENTNER Csaba

Nemzeti Közszolgálati Egyetem, Budapest, 2013

Tankönyv. Terjedelem: 341. Bibliográfia a fejezetek végén. ISBN 9786155344381

- A szerző egyetemi tanár, közgazdász. A könyv az egyetemi közigazgatási képzésben is oktatott közpénzügyek és államháztartástan szakirodalmát színesíti. A téma nagyon aktuális, és fontosságát jelzi, hogy a könyv előszavát a Magyar Nemzeti Bank és az Állami Számvevőszék elnöke írta. A szerző reagál a gazdasági válságot követő állami szerepváltozásokra, és bevezeti az olvasót az új magyar közpénzügyi rendszertan világába. Tizenkét fejezetben kifejtés tárgyát képezi többek között a közpénzügyek rendszertana, az államháztartás szerepe, az államháztartás központi és helyi alrendszerének föbb jellemzői, az államháztartás ellenőrzése, a fiskális és monetáris politika hazai szabályrendszere vagy épp a költségvetési szervek gazdálkodása. Az utolsó fejezet a hazai válságkezelés tapasztalataira és a közpénzügyi rendszer távlataira fókuszál. A kifejtettek megértését számos táblázat, ábra és diagram segíti. (B. P.)

- Környezeti adózás szabályozása a környezetpolitika rendszerében NAGY Zoltán Miskolci Egyetem, Miskolc, 2013 Monográfia. Terjedelem: 263. Bibliográfia: 251-263. és a lábjegyzetekben. ISBN 9789633580219

- A szerző egyetemi docens. A mü a környezeti adózás feldolgozását tüzte céljául oly módon, hogy közben eme fizetési kötelezettségeket a környezetpolitika eszközrendszerébe integrálja. A környezetpolitikai eszközrendszert a gazdasági szabályozási eszközök, kiemelten az adózás aspektusából közelíti meg. Az első rész a környezetpolitika és szabályozási eszközrendszerét mutatja be. A második részben az alapvetően pozitív irányú környezeti változások generálásának reményében bevezetett egyes adók bemutatására kerül sor, így megismerhetjük például az energiaadóra, az energiaellátók adóztatására, környezetterhelési díjra vagy épp a környezetvédelmi termékdíjra vonatkozó szabályokat. A mü hiánypótlónak tekinthető, mivel csak elvétve találkozni a környezet és pénzügyi jog metszetébe tartozó kérdéseket feszegető tudományos művekkel. (V. J.)

- Adózás és számvitel 2013

TomcsánYı Erzsébet-AlpÁr Ákos-BÁRdos Zoltán-BogdánY Viktor-BöRZsönYI Zsuzsanna-Kıss Zoltán-Kovács Attila-LAKı Gábor-LIPTÁK Péter-LóRÁnt SzabolcsNagy Viktória-Ozsváth Tímea-Szabó lldikó-Szabó Tímea-Zelina Erika

Ecovit Kiadó Kft., Budapest, 2013

Kézikönyv/tankönyv. Terjedelem: 256. Bibliográfia nincs. ISBN 9789638874382

- A szerzők gyakorlati szakemberek. A szóban forgó kiadvány egyaránt alkalmas gyakorlati szakemberek munkájának segítésére és a témával érdeklődő laikusok számára a szükséges alapvető ismeretek elsajátítására. Az első rész számviteli kérdéseket feszeget, ennek keretében kitér a számviteli törvény változásainak 
bemutatására, illetve a korábbi gazdasági társaságokról szóló törvény módosuló rendelkezéseire. A kiadvány második részében az egyes adókra és járulékokra vonatkozó anyagi jogi normák változásai kerülnek bemutatásra. A kiadvány érdeme, hogy nem korlátozódik kizárólag az anyagi jogi szabályokra, hanem kitér az egyes eljárásjogi előírások változásaira is, továbbá gyakorlati példákkal, ábrákkal és táblázatokkal segíti a megértést. (V. J.)

\section{POLGÁRI JOG}

- A nemzetközi gazdasági kapcsolatok joga

BÁNRÉVY Gábor

Szent István Társulat, Budapest, 2013

(Sorozat: A Pázmány Péter Katolikus Egyetem Jog- és Államtudományi Karának Könyvei 4., ISSN 1417-7285)

Tankönyv. Terjedelem: 227. Bibliográfia: 177-180. és a lábjegyzetekben.

ISBN 9789632772479

- A szerző egyetemi oktató. A kötet egyetemi hallgatók számára készült elsősorban, de a gyakorló jogászok is haszonnal forgathatják. A szerző először a nemzetközi gazdasági kapcsolatok joga közjogi kereteit vizsgálja, majd a nemzetközi gazdasági forgalom magánjogi viszonyait az egyes szerződéstípusokra vonatkozóan mutatja be. Az ismertetés az alanyok és a tárgy tisztázására épül. Az egyes szerződéstípusokat, így az adásvételi szerződést, a vállalkozási, megbízási, kooperációs, lízing-, licencia-, vállalatalapítási szerződéseket, továbbá az árufuvarozási, szállítmányozási és biztosítási szerződéseket, valamint fizetési ügyleteket öszszetetten, de didaktikailag tagoltan elemzi. A könyv végén megtalálható a Bécsi Konvenció szövege és egy részletes irodalomjegyzék nyújt további útmutatást a téma iránt érdeklődőknek. (T. E.)

- Új magyar polgári jog: Általános tanok

BíRó György-Lenkovics Barnabás

Novotni Alapítvány a Magányjog Fejlesztéséért, Miskolc, 2013

Egyetemi jegyzet. Terjedelem: 224. Bibliográfia: 217-219. ISBN 9630489694

- A szerzők egyetemi oktatók. A jegyzet a szerzőpáros által korábban megjelent, azonos címü könyvének az új Polgári Törvénykönyvhöz igazított kiadása. A korábban megszületett jegyzet szerkezetét követve hármas tagolásban (Bevezető rész - Jogszabálytan - Jogviszonytan) ismerteti a magánjog általános tanait. Az új Ptk. ihlette a tananyag megértését szolgáló példákat, valamint az általános tanok változásának folyamata is az új Kódexben való értékelésével kerül öszszegzésre. A jegyzet célja a polgári jogi tanulmányok megalapozása különösen a fogalmak, a polgári jogi normák szerkezete, valamint a jogviszonyok bemutatásán keresztül. (P. H.) 
- A személyek joga a 2013. évi V. törvény alapján: az új Polgári Törvénykönyv szövegének rövid magyarázata: ideiglenes jegyzet

CseHI Zoltán-NAVRATYIL Zoltán

Menedzser Praxis Szakkiadó és Gazdasági Tanácsadó Kft., Budapest, 2013 Jegyzet. Terjedelem: 214. Bibliográfia: 213. ISBN 9789638720696

- A szerzők egyetemi oktatók. A kötet azzal a céllal készült, hogy a részletes egyetemi jegyzetek megjelenéséig is az új Polgári Törvénykönyv szövegének tömör magyarázatával hozzájáruljon a jogszabály megismeréséhez, ennek megfelelően nem a teljesség igényével készült. A személyek jogának témakörén végighaladva, elöször bemutatja az új Ptk. Az ember mint jogalany c. könyvét, kitérve a jogképesség és cselekvőképesség kérdéseire. Ezt követően A jogi személy c. könyv ismertetésére kerül sor. A kalauz nem csupán az egyetemi hallgatók, hanem a gyakorló jogászok számára is hasznos összefoglaló. (T. E.)

- A Polgári Törvénykönyv: Ptk. 1959 - Ptk. 2013: Gt. 2006 - Ptk. 2013: Csjt. 1952 Ptk. 2013

\section{GÁrdos Péter}

CompLex, Budapest, 2013

Kézikönyv. Terjedelem: 819. Bibliográfia nincs. ISBN 9789632952802

- A szerző gyakorló ügyvéd és egyetemi oktató. A jogszabálytükör a Polgári Törvénykönyv hatálybalépését megelőzően, a Ptk. Gt. és a Csjt. 2011. január elsején hatályos szövegéhez rendeli az új Polgári Törvénykönyv megfelelő részét tükrös szerkezetben, amely által nyomon követhető az említett törvények továbbélése az új kódexben. Az egyes rendelkezések tükrös bemutatása közben a változásokat összefoglaló rövid leírás és magyarázat található. A szerző célja nem egy kommentár összeállitása volt, ennek szerepét a Vékás Lajos szerkesztésében megszülető „Polgári Törvénykönyv magyarázatokkal” című kötetre bízza. A könyv második szerkezeti egységében azon jogszabályok gyüjteménye található, amelyek 2014. március 15-töl az új Polgári Törvénykönyv részét képezik. Az új Ptk. szerkezete nem minden esetben követi a régi szerkezetét, tehát az egyes törvények és az új Kódex rendelkezései nem feleltethetőek meg egymásnak, amit a szerző külön leírásban jelez. A mű elsősorban az új Ptk. hatálybalépése előtt is a jogban már jártas szakembereknek szól, akik számára így könnyebben lekövethetővé és megérthetővé válnak az új szabályok. (P. H.)

- Geistiges Eigentum und Urheberrecht aus der historischen Perspektive. Internationaler Kongress Szeged, 17-19. Mai 2012

JAKAB Éva (Hrsg.)

Pólay Elemér Alapítvány, Szeged, 2013

(Sorozat: Lectiones luridicae, ISSN 2062 5588)

Tanulmánykötet. Terjedelem: 158. Bibliográfia nincs. ISBN 9786155300196

- A kötet a Szegeden, 2012-ben megrendezett nemzetközi konferencia anyagát tartalmazza, angol, német és magyar nyelvü tanulmányok formájában. A tanulmányok egy része történeti vagy dogmatikatörténeti megközelítést alkalmaz, másik részük a szellemi tulajdon modern kori, aktuális kérdéseit vizsgálja, mint példá- 
ul az alternatív vitarendezés lehetőségeit a német jog alapján, vagy egy színen fennálló szellemi tulajdonjog problémáját. (T. E.)

- A margón és azon túl: az intellektuális és pszichoszociális fogyatékossággal élő emberek cselekvőképességéről

JAKAB Nóra

Novotni Alapítvány, Miskolc, 2013

Monográfia. Terjedelem: 235. Bibliográfia: 211-230. ISBN 9789639360860

- A szerző egyetemi oktató. Könyve az intellektuális és pszichoszociális fogyatékossággal élő személyek cselekvőképességével foglalkozik, elsősorban polgári jogi szempontból. A kötet mind elméleti, mind gyakorlati szakemberek számára segítséget nyújthat az egyes jogszabályi rendelkezések értelmezéséhez. A szerző nem csak a magyar jogszabályokat elemzi: a témakörbe tartozó német, holland, brit, svéd tapasztalatokat is ismerteti, esettanulmányokat mutat be. Vizsgálat tárgyává teszi a fogyatékossággal élőkkel kapcsolatos nemzetközi tendenciákat, a cselekvőképességgel kapcsolatos elméleteket, a gondnoksági rendszereket, a a cselekvőképesség hazai szabályait, illetve azok tervezett módosításait az új polgári törvénykönyv megalkotására tekintettel. A kötet végén a szerző végkövetkeztetései találhatók. (B. K.)

- Magyar polgári jog I.

JobBÁGyı Gábor

Szent István Társulat, Budapest, 2013

Tankönyv. Terjedelem: 376. Bibliográfia a részek végén. ISBN 9789632774572

- A szerző egyetemi oktató. A tankönyv célja, hogy új megközelítéssel mutassa be a polgári jog anyagát, az új Ptk. alapján. A Személyek jogát a magánjogi hagyományoknak megfelelően egy kötetbe foglalja, így elemzésre kerülnek a természetes személyekre vonatkozó szabályok, a családjog és a szellemi alkotások joga. Mindez kiegészül egy Általános résszel, amely magában foglalja a polgári jog alapkérdéseit, tudománytörténetét, alapelveit, a jogszabálytant, a jogviszonytant és a jogi tények rendszerét is. A jogi személy bemutatását mellőzi, az anyag terjedelme miatt. Emellett az egész joganyag lényegretörő ismertetésére törekedett a szerző. A kötet az egyetemi hallgatók számára készült, és leegyszerűsített tartalmával jól szolgálhatja a vizsgákra való felkészülést. (T. E.)

- Stock corporations: a guide to initial public offerings, corporate governance and hostile takeovers

KECSKÉs András-HALÁSZ Vendel

HVG-ORAC, Budapest, 2013

Kézikönyv. Terjedelem: 566. Bibliográfia a lábjegyzetekben és 527-553.

ISBN 9789632582054 (Hungary), 9783700756729 (Austria)

- A szerzők egyetemi oktatók és gyakorló jogászok. A mú - ahogy arra a címe is utal - három fö részre tagolódik. Az egyes fejezetek keretében foglalkozik a részvények első nyilvános kibocsátása (IPO), a felelős vállalatirányítás, illetve a vállalatfelvásárlás kérdéseivel. Mind a három fejezetet végigkíséri az elmúlt évtizedben 
Magyarországon, az Európai Unióban, illetve az Egyesült Államokban alkalmazott jogi megoldások bemutatásának hármas tagolása. A szerzők figyelmet fordítanak a definíciók tisztázására, valamint az elméleti alapok feltárására, ezáltal mélyreható képet kap az olvasó a részvénytársaságok alapításával, irányításával, valamint a részvények kereskedelmével kapcsolatos kérdésekröl. A mü hasznos információkat tartalmaz jogászoknak, közgazdászoknak és ezen tudományokat elsajátítani kívánóknak egyaránt. (P. H.)

- Új Polgári Törvénykönyv: aktuális kérdések

Koller Kármen Csenge-Tar Adrienn (szerk.)

ELTE Bibó István Szakkollégium, Budapest, 2013

Tanulmánykötet. Terjedelem: 249. Bibliográfia a fejezetek végén és a lábjegyzetekben. ISBN 9786638870056

- A tanulmánykötetet az ELTE Bibó István Szakkollégium Új Ptk.-kutatócsoport hallgatói jegyzik. A kutatócsoport tagjai a kodifikáció eredményeinek feldolgozása mellett átfogó képet kívánnak alkotni az új Ptk.-ról: a hallgatók komplex módon gyűjtötték össze és gondolták át a jogalkalmazás során felmerült kihívásokra adott jogalkotói válaszokat. A kötet tartalmaz tanulmányokat többek között a személyiségvédelem, a dologi jog, a kötelmi jog, valamint az öröklési jog körében is. (B. L.)

- A fogyasztóvédelmi jog európai gyökerü magyar szabályozása

MiskolCZI BOdNÁR Péter-SÁndOR István

(Sorozat: Bethlen-sorozat, ISSN 2062-2546)

Patrocinium, Budapest, 2013

Jegyzet. Terjedelem: 138. Bibliográfia a lábjegyzetekben. ISBN 9786155337383

- A szerzők egyetemi tanárok. A mű elsősorban egyetemi hallgatóknak nyújt a vizsgára való felkészüléshez segítséget. Bemutatja a fogyasztóvédelem célját és sajátosságait, jogrendszerben elfoglalt helyét, részletesen ismerteti a fogyasztók érdekeit védeni hivatott normák, jogintézmények szabályait. Az utolsó tartalmi egység a fogyasztók igényérvényesítési lehetőségeit veszi sorra, a különböző hivatalok, békéltető testület és bírósági eljáráson át, ideértve a közérdekű keresetek ismertetését. (B. L.)

- Nemzetközi magánjog és nemzetközi gazdasági kapcsolatok joga: Kiegészítö jegyzet (Záróvizsga tételek szerinti bontásban)

MoLnÁR István János-Osztovits András Mihály-PALÁstı Gábor Péter

(Sorozat: Werböczy-sorozat, ISSN 2062 2538)

Patrocinium, Budapest, 2013

Egyetemi jegyzet. Terjedelem: 241. Bibliográfia nincs. ISBN 9786155337123

- A szerzők az egyetemi hallgatók nemzetközi magánjog záróvizsgájához kívánnak segítséget nyújtani ezzel a kiegészítő jegyzettel, amelynek tagolása is követi a záróvizsga tételsorát. A munka két „kötetre” osztott: nemzetközi magánjog és nemzetközi gazdasági kapcsolatok joga, amelyek keretében végigveszi a nemzetközi magánjog tárgy keretében oktatott tematikát. (T. E.) 
- Általános szerződési feltételek, tisztességtelen szerződési kikötések NEMESSÁNYI Zoltán (Sorozat: Bírói Gyakorlat Füzetek, ISSN 2063-725X; 2.)

Opten, Budapest, 2013

Döntvénytár/kézikönyv. Terjedelem: 162. Bibliográfia nincs.

ISBN 9786155122118

- A szerző egyetemi oktató, és jelen múvében a Polgári Törvénykönyvröl szóló 1959. évi IV. törvény (régi Ptk.) általános szerződési feltétellel kapcsolatos szabályozását elemzi. A szerző az általános szerződési feltétel fogalmát követően, az általános szerződési feltételnek a szerződés részévé válását, majd a tisztességtelen szerződési feltételt és végezetül a közérdekű keresetet ismerteti az egyes jogintézmények értelmezése tekintetében irányadó bírósági gyakorlat bemutatásával. A szerző az ügy tényállásának és a bíróság döntésének bemutatását követően valamennyi ítéletet értékeli. (B. L.)

- Az új Ptk. konverziós táblája

Nemessányi Zoltán-Osztovits András (szerk.)

Opten, Budapest, 2013

Kézikönyv. Terjedelem: 707. Bibliográfia nincs. ISBN 9786155122040

- A kötet az 1959. évi IV. törvényt (régi Ptk.) és a 2013. évi V. törvény szövegét veti össze, táblázatos formában. A változások tipográfiailag is megjelennek, ezzel is segítve az összehasonlítást. A kötetben az egyes szabályok egymásnak megfeleltetve találhatók meg, a régi Ptk. és egyéb hozzá tartozó jogszabályok számozását követve. A munka a szerkesztők szándéka szerint nem kommentár, kizárólag a megismerést kívánja szolgálni, és egyben a szerkesztők tiszteletét kifejezni az új Ptk. megalkotóinak „szellemi teljesítménye előtt”. A kézikönyv minden jogász számára hasznos lehet, az új Ptk.-val való ismerkedés első lépéseként. (T. E.)

- Ünnepi tanulmányok Kecskés László professzor 60. születésnapja tiszteletére Nochta Tibor-Fabó Tibor-Márton Mária (szerk.)

PTE ÁJK, Pécs, 2013

Tanulmánykötet. Terjedelem: 615. Bibliográfia a lábjegyzetekben. ISBN 9789636425593

- A tanulmánykötet Kecskés László, a PTE ÁJK egyetemi tanárának, nemzetközi hírủ professzorának 60 . születésnapjának tiszteletére készült. Az ünnepelt széles körü tudományos érdeklődésének megfelelöen a kötet az egyes tanulmányokkal a polgári jog széles spektruma képviseletet nyer. A kötelmi jogi és gazdasági magánjogi tanulmányok mellett helyet kapnak a családi jogi, a nemzetközi magánjogi, európai jogi és jogfilozófiai alkotások is a kötetben. A tanulmányok szerzőit az adott téma legjelesebb magyarországi képviselői alkotják, magyar, angol és német nyelven. (B. L.) 
- Opuscula civilia: Magánjogi látlelet $=$ Report on Hungarian private law $=$ Befundbericht über das ungarische Privatrecht

PAPP Tekla

Lectum, Szeged, 2013

Monográfia. Terjedelem: 278. Bibliográfia a lábjegyzetekben.

ISBN 9789639640450

- A szerző a Szegedi Tudományegyetem és a Nemzeti Közszolgálati Egyetem oktatója. A könyv magyar, angol és német nyelven íródott. A szerző elsősorban az új Polgári Törvénykönyv kodifikációja során felmerült nehézségekre fókuszál, ennek keretében foglalkozik többek között a szerződések tipizálásával, a fogyasztó fogalmával, illetve a jogi személyekkel és a jogi személyiség nélküli gazdasági társaságokkal kapcsolatban felmerült problémákkal. (P. H.)

- Polgári jog: kommentár a gyakorlat számára: a 2013. évi V. törvény, az új Ptk. kommentárja

Petrik Ferenc (szerk.)

3. kiadás, HVG-ORAC, Budapest, 2013

Kommentár. Terjedelem: 2462. Bibliográfia nincs. ISBN 9789638213655

- A szerkesztők és a szerzők között találunk jogtudósokat, gyakorló jogászokat és kodifikátorokat egyaránt. Az elsősorban gyakorlatias szemléletü kommentár kapcsos borítóban két kötetben jelent meg, amelyből az első kötet a Kódex első három könyvét (Bevezető rendelkezések, Az ember mint jogalany, A jogi személy) mutatja be, a második kötet pedig a Negyedik és az Ötödik Könyvet taglalja (Családjog, Dologi jog). A harmadik, átdolgozott kiadás az egyes rendelkezések bemutatása mellett ismerteti az új szabályozás indukálta változások joggyakorlat szintjén várható irányát. Ezzel érthetöbbé válnak az új Polgári Törvénykönyv rendelkezései, amely folytán a kommentár segítséget nyújt a gyakorló jogászoknak és a jogtudománynak egyaránt. (P. H.)

\section{- Előadásvázlatok a személyek jogából}

SÁNDOR István

(Sorozat: Bethlen-sorozat, ISSN 2062-2546)

Patrocinium, Budapest, 2013

Oktatási segédanyag. Terjedelem: 229. Bibliográfia a fejezetek végén és 220-229. ISBN 9786155337376

- A szerző egyetemi oktató. A kötetben a szerző korábbi, a személyek joga tárgykörében tartott egyetemi előadásainak anyaga található, átdolgozva az új Ptk. szabályai alapján és a vizsgáztatási tapasztalatokat is figyelembe véve. A kötet nemcsak a vizsgára való felkészítés elősegítését célozza, hanem kiindulópontot is kíván nyújtani a témában való elmélyültebb kutatáshoz. Ehhez bőséges irodalomjegyzékkel és a korábbi bírói gyakorlatra való hivatkozásokkal kíván hozzájárulni. A munka a lehetséges mértékben mellőzi a jogi személyeknek a kereskedelmi jog területére eső anyagát. (T. E.) 
- A fogyasztói pénzügyi lízing

VARGa Nelli

HVG-ORAC, Budapest, 2013

Monográfia. Terjedelem: 260. Bibliográfia: 242-260. ISBN 9789632582313

- A szerző egyetemi oktató. A kötet pontosan lehatárolt körben, a lízingszerződések közül a nagyobb gyakorlati jelentőséggel bíró pénzügyi lízinget és annak fogyasztói szerződésben előforduló változatát mutatja be, komplex szemlélettel. A munka hangsúlyozni kívánja a fogyasztói jogok többletvédelmének szükségességét, és a vonatkozó jelenlegi szabályozás anomáliáit. A kötet érdeme, hogy tudományos szempontból közelíti meg a témát, a pénzügyi lízinget elhatárolja más hasonló elemekkel rendelkező szerződéstípusoktól, ugyanakkor a joggyakorlat és a szerződéskötési gyakorlat tapasztalatait is beépíti a szerző. Elsősorban a fogyasztóvédelem iránt érdeklödők számára lehet hasznos kézikönyv, de a mindennapi életben ilyen szerződéssel foglalkozók, vagy ilyen típusú szerződést kötni kívánó laikusok számára is eligazodási pontot képez. (T. E.)

\section{- A Polgári Törvénykönyv magyarázatokkal}

Vékás Lajos (szerk.)

CompLex, Budapest, 2013

Kommentár. Terjedelem: 1086. Bibliográfia nincs. ISBN 9789632952789

- A kommentár szerkesztője az MTA tagja és az ELTE Állam- és Jogtudományi Kar Polgári Jogi Tanszékének professor emeritusa, emellett a Kodifikációs Bizottság elnöke; társszerzői kúriai bírák, jogtudósok, gyakorló jogászok, akik a kodifikációs munkálatok aktív szereplői voltak. A mü a törvény szerkezetét követve ismerteti annak rendelkezéseit, amelyeket az egyes fejezetek végén részletes indoklás követ. Ennek keretén belül kerülnek ismertetésre azon bírósági ítéletek, kollégiumi állásfoglalások, jogegységi határozatok, amelyek a régi Polgári Törvénykönyv nyomán születtek, de jelentőségüknél fogva meghatározták az új Kódex normaszövegét is. A mű ezeken túlmutatva teljes képet ad arról is, milyen változtatásokra volt szükség a korábbi Polgári Törvénykönyvben és a bírói gyakorlat terén, amelyek részletes indoklására is sor kerül. Egyaránt ajánlott a gyakorlatban dolgozó jogászoknak és a mindenre kiterjedő indoklás miatt pedig a jogtudomány számára is haszonnal forgatható. (P. H.)

- Magyar polgári jog: Öröklési jog

VéKÁs Lajos

7., átdolgozott kiadás, ELTE Eötvös, Budapest, 2013

Oktatási segédanyag. Terjedelem: 158. Bibliográfia a fejezetek végén.

ISBN 9789639955424

- A szerző egyetemi oktató. A kötet kifejezetten egyetemi hallgatók számára készült. Az öröklési jog témakörében a szerző nem csak a hatályos öröklési jogi szabályok bemutatásán túlmenően több esetben kitér a téma elméleti és történeti vonatkozásaira is. Az újabb kiadást és átdolgozást a 2013. évi V. törvény, az új Ptk. elfogadása indokolta. (T. E.) 
- Szomszédjogok

VILLÁm Krisztián

(Sorozat: Bírói Gyakorlat Füzetek, ISSN 2063-725X; 2.)

Opten, Budapest, 2013

Döntvénytár/kézikönyv. Terjedelem: 183. Bibliográfia nincs.

ISBN 9786155122033

- A könyv szerzője jelen müvében a Polgári Törvénykönyvröl szóló 1959. évi IV. törvény (régi Ptk.) szomszédjogi szabályain (régi Ptk. 100-106. §§) alapuló bírósági gyakorlatot mutatja be. A szerző a szomszédjog általános szabályának ismertetését követően az építkezéssel okozott zavarás, a növényzet elhelyezése folytán felmerült zavarás, a közös határral kapcsolatban megvalósult zavarás, a zaj okozásával bekövetkező zavarás, valamint az állattartással összefüggésben előálló zavarás következtében felmerült szomszédjogi tényállásokat mutatja be „vezető” bírósági döntések segítségével. A szerző az ügy tényállásának és a bíróság döntésének bemutatását követően valamennyi ítéletet értékelés alá vonja. (B. $L$.)

- Nagykommentár a tisztességtelen kereskedelmi gyakorlatról szóló törvényhez: nagykommentár a fogyasztókkal szembeni tisztességtelen kereskedelmi gyakorlat tilalmáról szóló 2008. évi XLVII. törvényhez

ZAVODNYIK József

CompLex, Budapest, 2013

Kommentár. Terjedelem: 414. Bibliográfia: 401-402. ISBN 9789632953472

- A szerző a Gazdasági Versenyhivatal tagja. A nagykommentár a fogyasztókkal szembeni tisztességtelen kereskedelmi gyakorlat tilalmáról szóló 2008. évi XLVII. törvény rendelkezéseit értelmezi a törvény szerkezetéhez igazodva. $A z$ egyes szakaszok után bemutatásra kerül a kapcsolódó szakirodalom, valamint Magyarország és az Európai Unió joggyakorlata, amely segítséget nyújt a jogalkalmazásnak az egyes rendelkezések könnyebb értelmezéséhez. A bíróságok joggyakorlatát kiegészítve a minél teljesebb megismerés érdekében többek között a Gazdasági Versenyhivatal és a fogyasztóvédelmi hatóság előtti eljárások is bemutatásra kerülnek. A jogszabályi környezet könnyebb megértését szolgáló magyarázat, valamint a gyakorlat részletes bemutatása okán a jogászoknak és a vállalatoknak egyaránt ajánlott. (P. H.)

\section{VEGYES TÁRGYÚ KÖTETEK}

- Hagyomány és érték - Állam- és jogtudományi tanulmányok a Károli Gáspár Református Egyetem fennállásának 20. évfordulójára

Antalóczy Péter (szerk.)

Károli Gáspár Református Egyetem Állam- és Jogtudományi Kar, Budapest, 2013 Tanulmánykötet. Terjedelem: 370. Bibliográfia az egyes tanulmányok végén.

ISBN 9879639808508

- A szerzők a Károli Gáspár Református Egyetem Állam- és Jogtudományi Karának oktatói. A kötet az egyetem huszadik éves fennállásának kíván emléket állítani, 
s tanszékekre tagolva tartalmazza az egyetem oktatóinak tanulmányait. A kötet összesen harmincegy tanulmányt tartalmaz, melyek a legkülönbözőbb témákban íródtak nagyobbrészt magyar, kisebb részben angol nyelven. A témák sokszínúsége miatt e kötet a jogtudományok bármely ágával foglalkozó olvasó számára hasznos lehet. (D. V.)

- Etikák, identitások, perspektívák - Szemelvények az erkölcselmélet és a kortárs hivatásetikák köréből

Bertók Rózsa-Barcsi Tamás (szerk.)

Virágmandula Kft., Ethosz Tudományos Egyesület, Pécs, 2013

Tanulmánykötet. Terjedelem: 408. Bibliográfia a tanulmányok végén. ISBN 9789638814944

- A szerkesztők és a tanulmányok szerzői egyetemi oktatók. A könyv alapvetően filozófia- és erkölcselméleti munkákat tartalmaz, amelyeken túl azonban külön fejezet foglalkozik a gazdaság, a politika és a jog erkölcsi dimenzióival, így tehát maga a jog is a tanulmánykötet fókuszában áll. A tanulmányok tudományos konferenciákon elhangzott előadások anyagai, négy nagy fejezetbe osztva. Így olvashatunk az erkölcsi kérdések elméleti alapjairól, a gazdaság, a politika és a jog erkölcsi dimenzióiról, a pedagógia és az erkölcs, valamint az erkölcs és a múvészet kapcsolatáról. A joggal foglalkozó fejezeten belül olyan kérdések tárgyalására kerül sor, mint a közjó, az igazságosság, a jogállam fogalma, az erkölcs és a jog kapcsolata, a közszolgálati etika alapkérdései. (B. K.)

- Állam és jog: kodifikációs kihívások napjainkban

Fantoly Zsanett-Gácsi Anett Erzsébet (szerk.)

(Sorozat: Szegedi Jogász Doktorandusz Konferenciák, ISSN 2063-3807; 3.)

Generál Nyomda Kft., Szeged, 2013

Tanulmánykötet. Terjedelem: 272. Bibliográfia a lábjegyzetekben.

ISBN 9789636934644

- A kötet a Szegeden, 2012. május 30-án azonos címmel rendezett tudományos konferencián a doktorandusz résztvevőktől a szekcióüléseken elhangzott előadások tanulmánnyá átdolgozott változatait tartalmazza. A 24 tanulmány a legkülönfélébb témákat dolgozza fel a büntetőjog, a polgári jog és a közjog területén. Olvashatunk írást például a kettős állampolgárságról, az új magyar adó- és vámigazgatásról, a licenciaszerződésről, a helyi önkormányzatok feletti törvényességi kontroll szabályairól vagy az egyházként való elismerés megváltozott rendszeréröl. A konferencia plenáris előadásainak szerkesztett változatai - többek között Paczolay Péter, Stumpf István, Varga Zs. András tollából - külön kötetben jelentek meg, szintén 2013-ban. (Zs. V.) 
- Jogi ismeretek a gyakorlatban

Kecskés András (szerk.)

[Számozatlan], bővített, átdolgozott kiadás. Penta Unió, Pécs, 2013

Tankönyv. Terjedelem: 466. Bibliográfia: 451-453. ISBN 9786155249112

- A szerzők a felsőoktatásban, illetve az ügyvédi gyakorlatban dolgozó, a polgári jog, kereskedelmi jog területén elismert szakemberek. A mủ célja, hogy áttekintést nyújtson valamennyi jelentős jogterület alapvető szabályairól, így a polgári jog, kereskedelmi jog, munkajog, közigazgatási hatósági eljárásjog, büntetőjog területén irányadó hatályos szabályokról. Külön fejezet foglalkozik a követelések érvényesítésének jogi alapjaival. A könyv már az új kódexek (Ptk., Btk., Mt.) szabályanyagát dolgozza fel, érthető alapismereteket nyújtva a jogkereső állampolgárok, valamint a jogász, a jogi és gazdasági alapképzések részeként jogi ismeretek tárgyat hallgatók részére. (Ny. A.)

\section{- A SZE Állam- és Jogtudományi Doktori Iskolájának első 5 éve} Kecskés Gábor (szerk.)

Széchenyi István Egyetem Állam- és Jogtudományi Doktori Iskolája, Győr, 2013 Jubileumi kötet. Terjedelem: 258. Bibliográfia a lábjegyzetekben. ISBN 9786155391064

- A szerkesztő egyetemi adjunktus, a doktori iskola titkára. A kiadvány bemutatja a doktori iskola tényszerű adatait (törzstagok, témavezetők, oktatók, kutatási témák és kurzusok magyar és angol nyelven egyaránt), a megvédett értekezések egykét oldalas összegzését (ugyancsak magyar és angol nyelven), valamint a doktori iskolához kötődő törzstagok, oktatók, illetőleg a doktori iskola által szervezett nyári egyetem résztvevői által írt, válogatott tanulmányokat is közöl. A kiadvány kiváló bemutatása az egyik legújabb állam- és jogtudományi doktori iskola mủködése első éveinek. (Sz. S.)

- Jogi alapismeretek technológiaalapú vállalkozásoknak

MoLnÁR István

(Sorozat: Fundamenta Fontium luris, ISSN 2061-1609)

lurisperitus Bt., Szeged, 2013

Tankönyv. Terjedelem: 171. Bibliográfia: 171. ISBN 9789630864725

- A szerző kutató vegyész és jogász, szabadalmi ügyvivő. A kötet kiindulási pontja a címétől eltérően nem a jog, hanem a termelés mint értékteremtő folyamat. A munka túlmutat a szakzsargonban technológiajogként definiált területen, magába foglalja mindazokat a jogterületeket, amelyekkel a mérnökök találkozhatnak munkájuk során. Így áttekintésre kerülnek a jog alapvető fogalmai, a jogforrások, a közigazgatási jog, a gazdasági jog vonatkozó részei a polgári és munkajoggal együtt, a versenyjog és a szellemi alkotások jogának egyes kérdései, az agrár- és környezeti jog, valamint a polgári jogi és büntetőjogi felelősség egyes releváns részei. A könyv célja, hogy a mérnökök körében kialakuljon a helyes jogértelmezés készsége. A szerző szándéka szerint egyszerre segíti a mérnökképzést szakkönyvként, de a gyakorló mérnökök számára is hasznos ,jogi kisokos” lehet. (T. E.) 
- The Transformation of the Hungarian Legal System 2010-2013

Smuk, Péter (szerk.)

CompLex, Budapest, 2013

Tanulmánykötet. Terjedelem: 473. Bibliográfia a lábjegyzetekben. ISBN 9789632953434

- A kötetben szereplő tanulmányok szerzői a győri Széchenyi István Egyetem jogi karán 2012-2013-ban müködött kutatócsoport tagjai. A kutatás és az angol nyelvü kötet célja volt, hogy átfogó képet adjon a szakmai közönségnek a magyar jogrendszer 2010-2013 között végbement átalakulásáról. A kötetnek nem volt célja a jogrendszer átalakítása mögötti politikai indokok feltárása, a szerzők kizárólag jogi elemzést készítettek az egyes jogterületeken bekövetkezett jogszabályi és intézményi változásokról. A kötet külön fejezetben foglalkozik az új alkotmánnyal és a közjogi rendszer átalakulásával, az új Polgári Törvénykönyvvel, az új büntetőjogi szabályozással és az új munkajogi környezettel. (B. É.)

- Jogi alapismeretek - Bölcsészeknek és társadalomtudósoknak

Sztárayné Kézdy Éva (szerk.)

(Sorozat: Bethlen-sorozat, ISSN 2062-2546.)

Patrocinium, Budapest, 2013

Egyetemi jegyzet. Terjedelem: 302. Bibliográfia az egyes fejezetek végén. ISBN 9786155337109

- A szerzők a Károli Gáspár Református Egyetem oktatói. A jegyzet elsősorban az egyetem bölcsészettudományi karán tanuló hallgatók számára íródott. Az államés jogtudományokba nyújt betekintést, amelynek keretében a jogtörténeti áttekintést követően a jog és az állam alapvető fogalmait tisztázza, majd egyes jogágak (az alkotmányjog, a polgári jog, a büntetőjog, a munkajog) rövid bemutatása következik a hatályos jogszabályok alapján. Tekintettel a bölcsészkaron oktatott stúdiumok sajátos igényeire, a könyv külön fejezetet szentel a médiajognak és az Európai Unió jogának. A jegyzet célja elsősorban a széles társadalomtudományi tudás megalapozása a bölcsészhallgatók számára. (P. H.) 